موسى خليل عودذ؛ عبير محمد الوحيدي

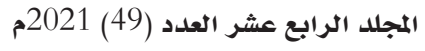

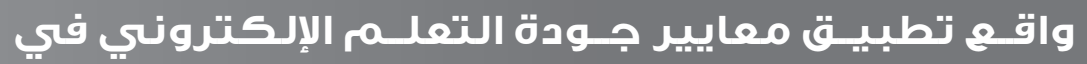

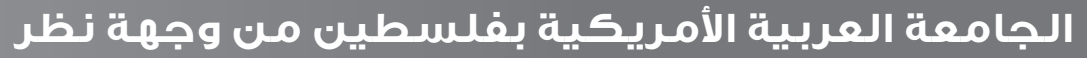
أعضاء هيئة التوريس بفس فيسن

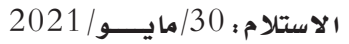

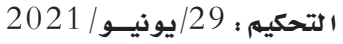

القبـــول : 28 أغسطس /2021

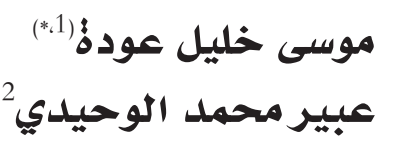

() 2021 University of Science and Technology, Yemen. This article can be distributed under the terms of the Creative Commons AttributionLicense, which permits unrestricted use, distribution, and reproduction in any medium, provided the original author and source are credited.

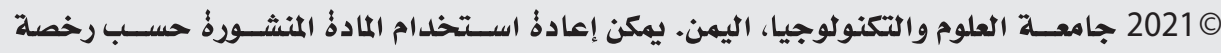
مؤسسة المشاع الإبداعي شريطة الاستشهاد بالمؤلف والمجلة المألة. 


\section{واقع تطبيق معايير جـودة التعلمم الإلكتروني في الجامعة العزبة العربية

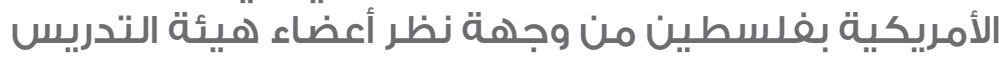

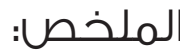

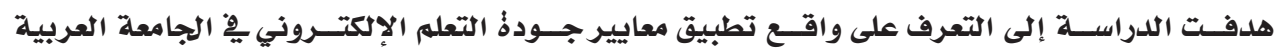

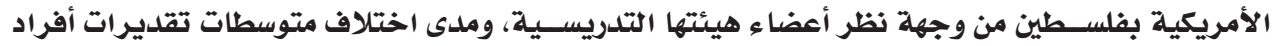

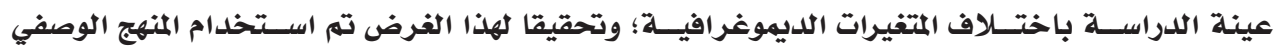

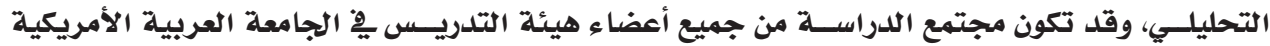

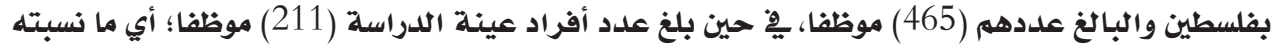

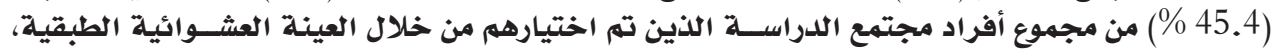

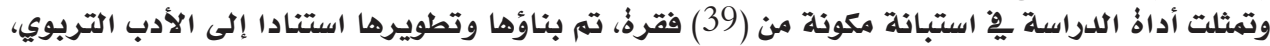

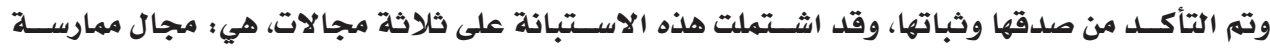

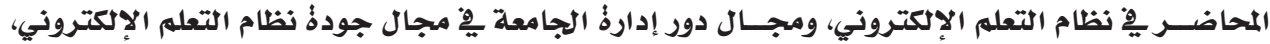

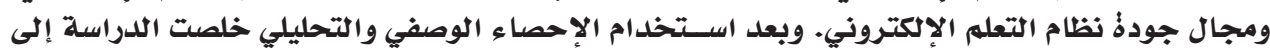

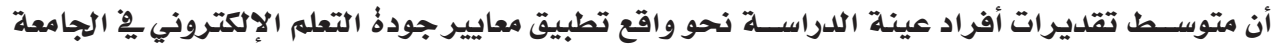

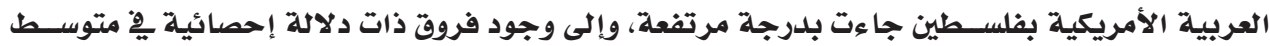

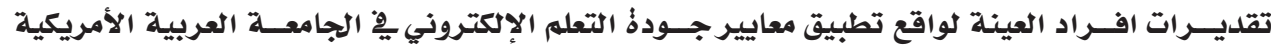

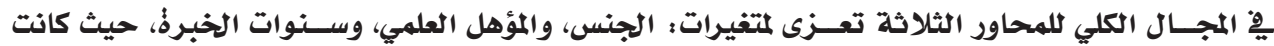

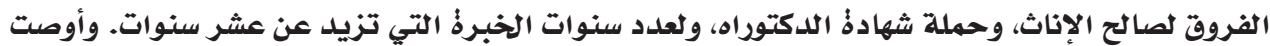

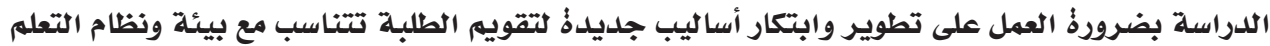

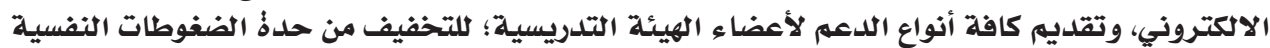

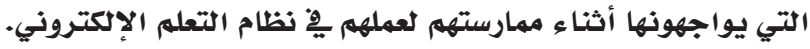
الكلمات المفتاحية : التعلم الاكتروني، معايير جودذٌ التعلم الالكتروني، الجامعة العربية الأمريكية. 


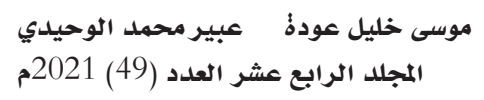

\title{
The Current Status of Applying E-Learning Quality Standards from the Perspective of Faculty Members at Arab American University
}

\begin{abstract}
:
The study aimed to identify the current status of applying e-learning quality standards at the Arab American University from the point of view of faculty members, and to what extent average means differ according to the different demographic variables. To achieve this, the descriptive analytical method was used, and (211) members were randomly selected, who represented $(45.4 \%)$ of the study population (465) faculty members working at the Arab American university. A questionnaire consisting of (39) items covering (3) dimensions (the lecturer's role in using e-learning system, the quality of e-learning system, the role of the university administration in the quality of e-learning system) was used after testing its validity and reliability. After the descriptive statistical analysis, the results showed that the average means of the study sample towards the current status of applying the quality standards of e-learning at the university received a high degree. There were also statistically significant differences in the gender variable in favor of females; in qualification in favor of $\mathrm{PhD}$ holders; and in experience in favor of (more than 10 years). The study concluded with a number of recommendations, including developing and innovating new methods of evaluation suitable for the e-learning system, providing all kinds of support to faculty members, and relieving the psychological stress faced during the e-learning process.
\end{abstract}

Keywords: e-learning, quality of e-learning systems, Arab American University. 


\section{المقدمة:}

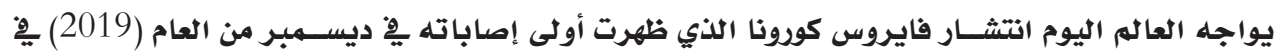

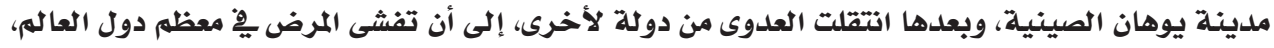

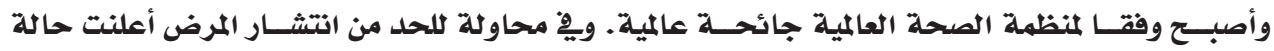

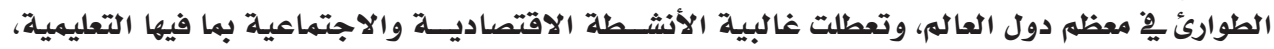

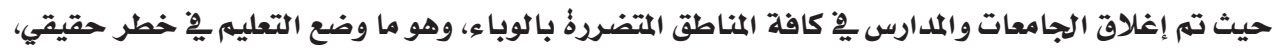

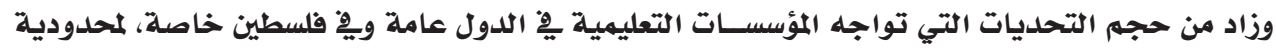

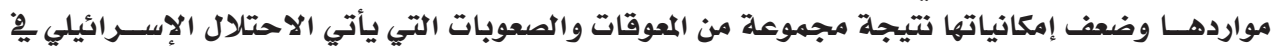

مقدمتها.

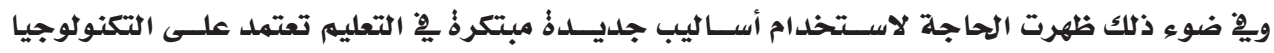

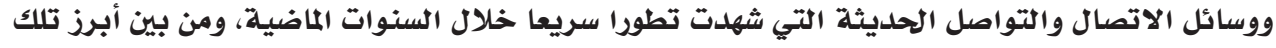

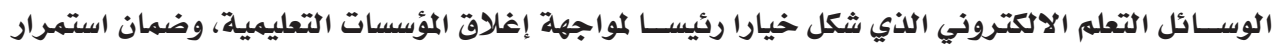

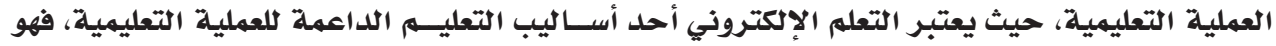

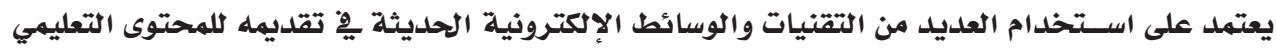

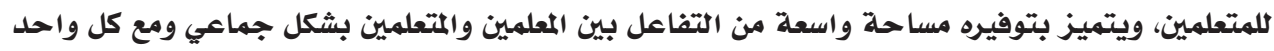

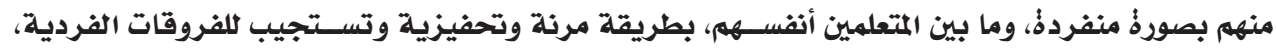

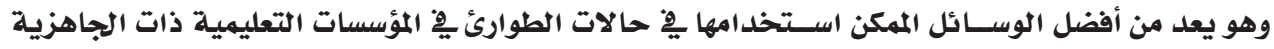

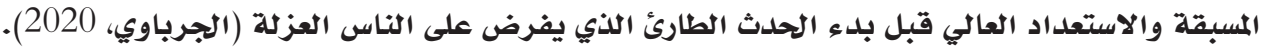

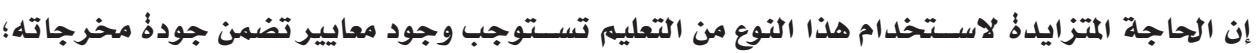

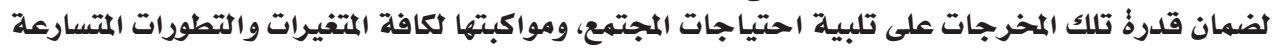

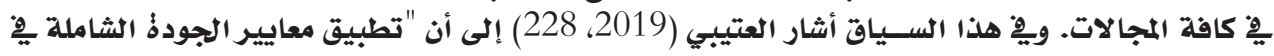

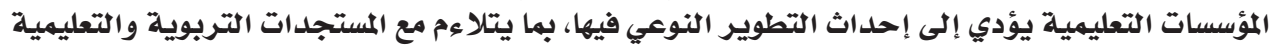

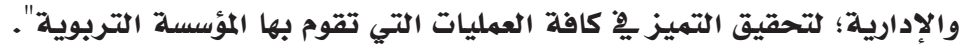

ونظرا لاعتماد كافة المؤسسـات التعليمية الفلسطينية ومن بينها الجامعة العربية الأمريكية على التعلم

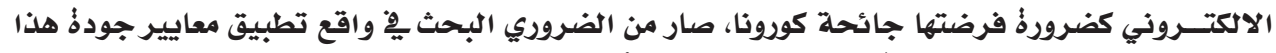

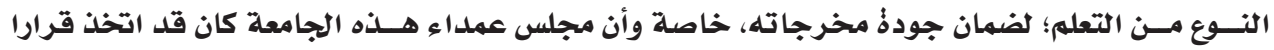

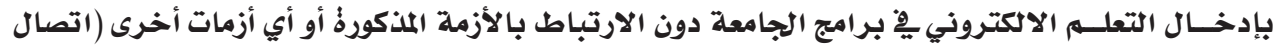

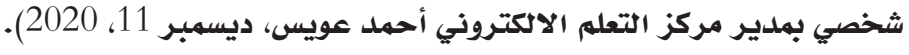
مفهوم التعلى الالكتروني:

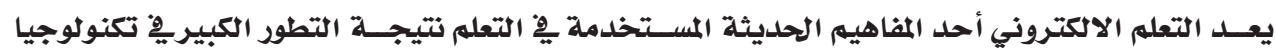

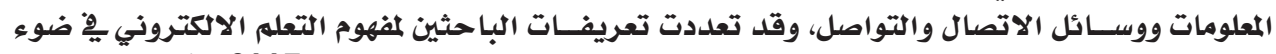

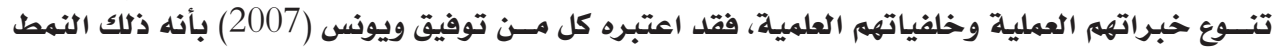

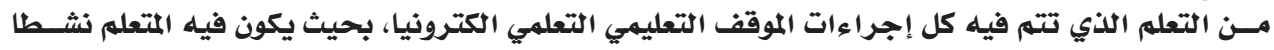

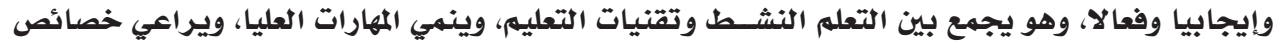

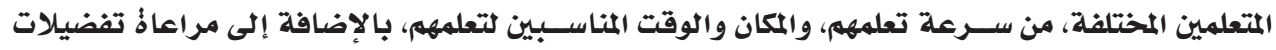

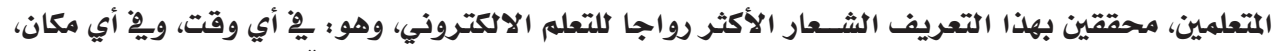

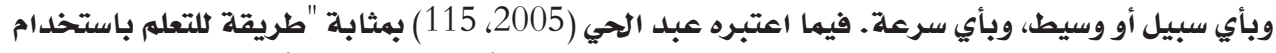

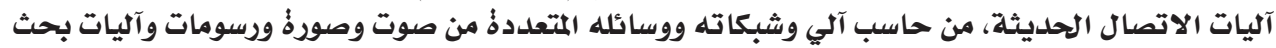

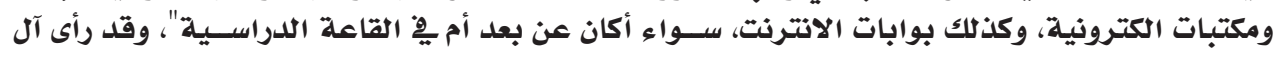




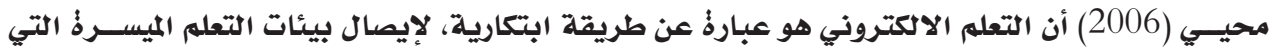

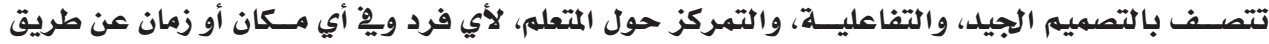

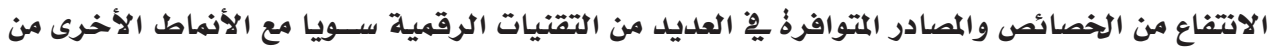

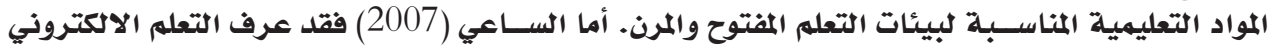

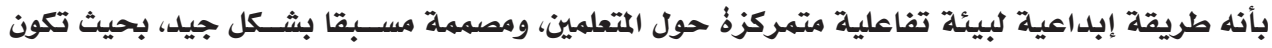

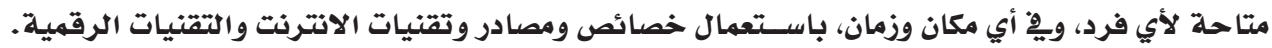

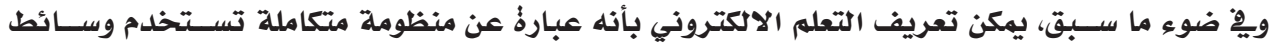

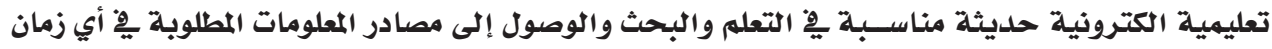

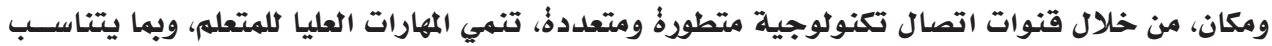

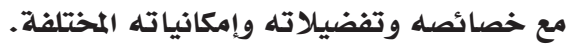

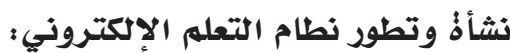

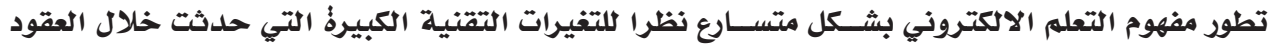

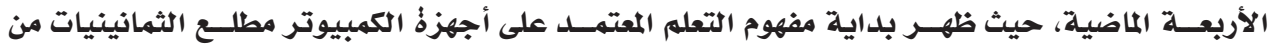

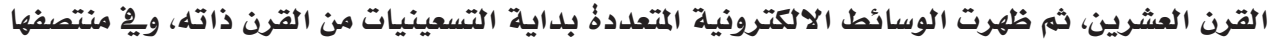

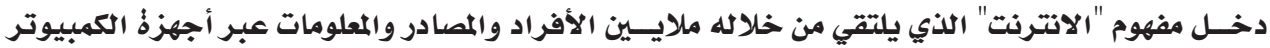

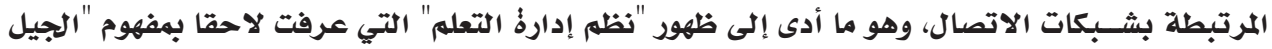

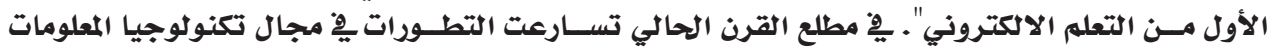

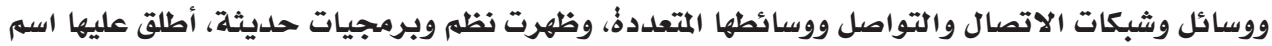

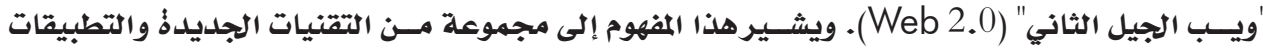

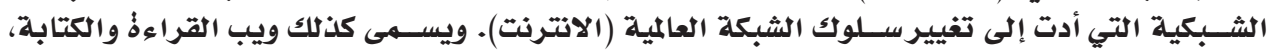

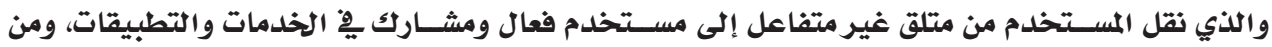

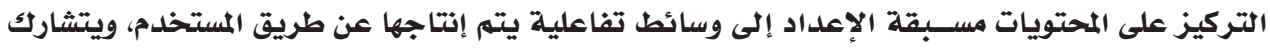
فيها مع الآخرين (لال، 2008).

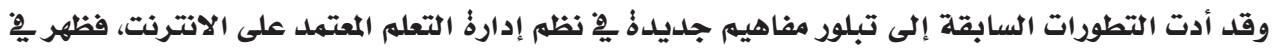

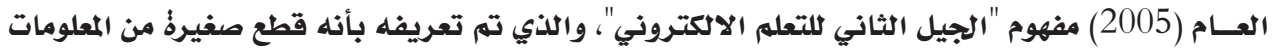

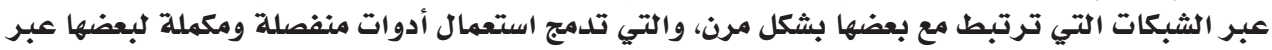

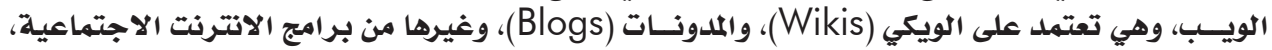

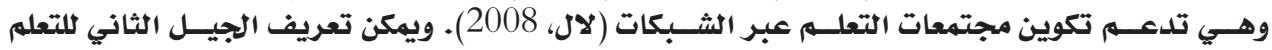

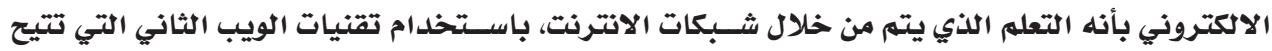

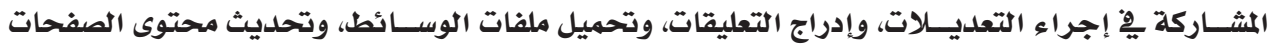

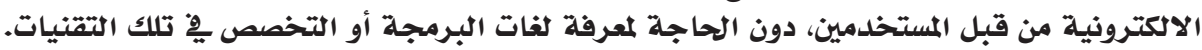

جودة: التعله الاكتكتروذي:

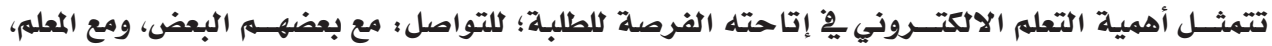

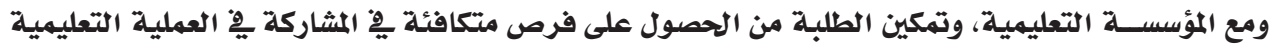

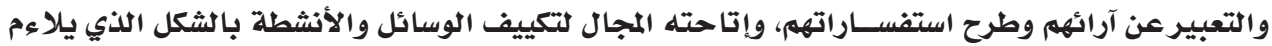

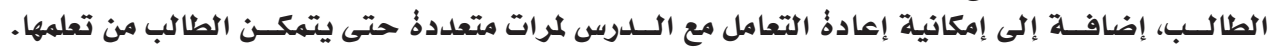

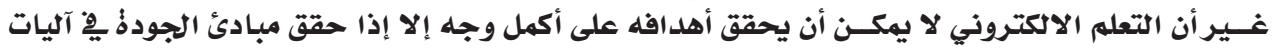

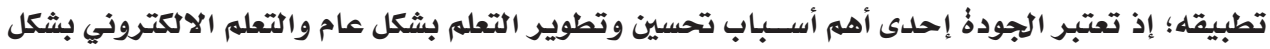
خاص، وإخضاع هذه الآليات لمبادئ الجودذٌ يسهم يِّ التعرف على المعيقات التي تحول دون تحقيق الأهداف المرجوةٌ (الحربي، 2013). 
وقد عرف العتيبي (2019، 232) مفهوم جودةٌ التعلم الالكتروذي بأنه :

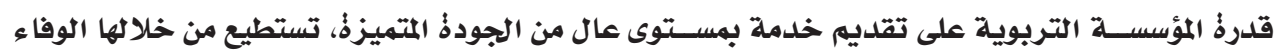

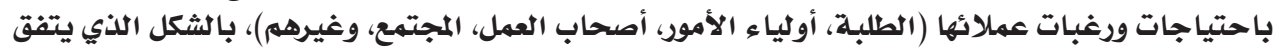

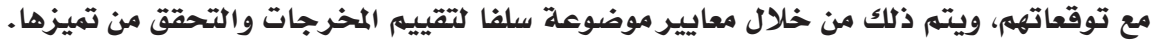

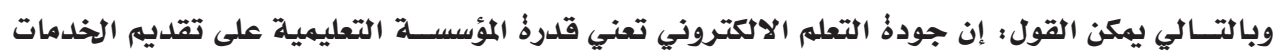

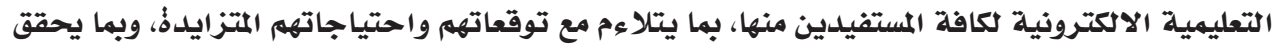

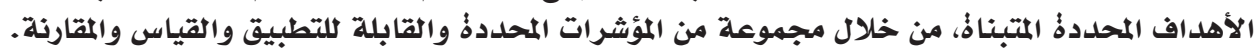

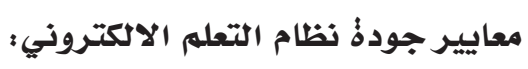

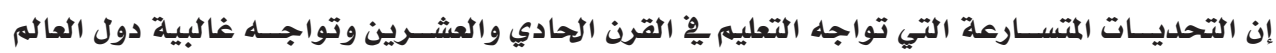

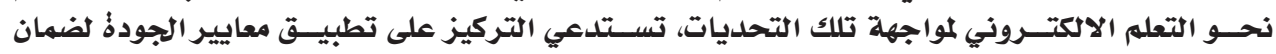

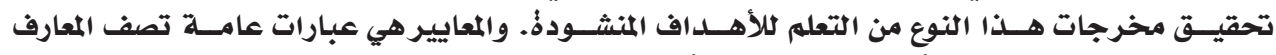

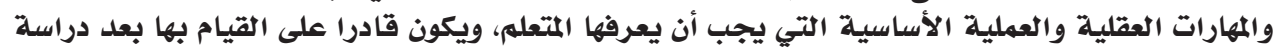

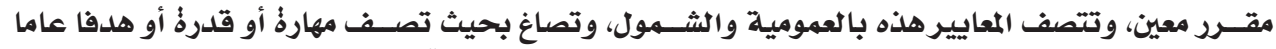

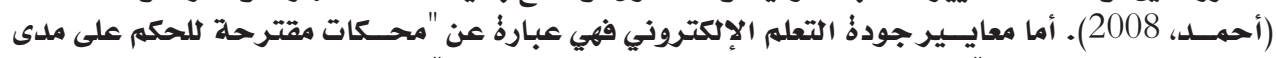

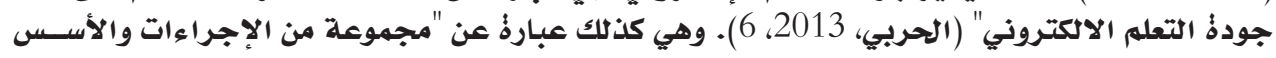

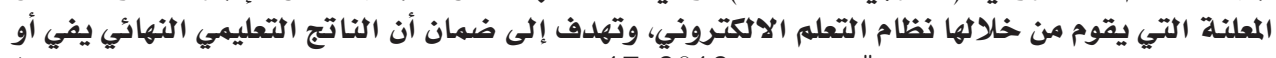

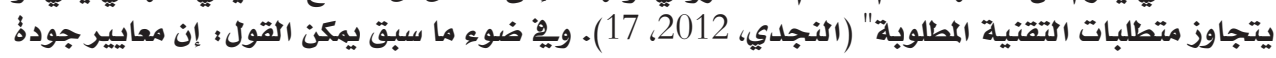

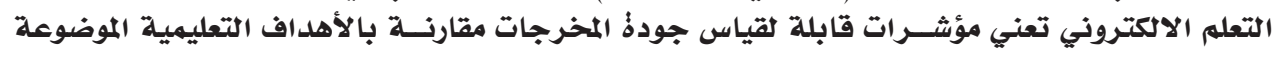

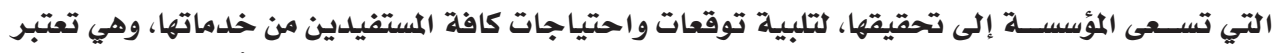

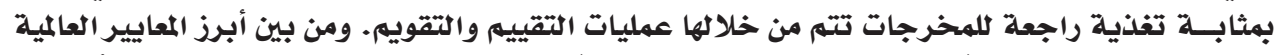

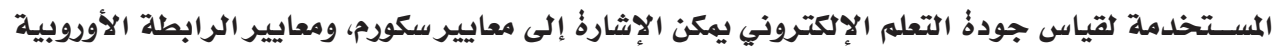
لجامعات التعلم عن بعد.

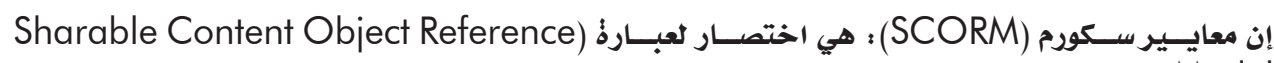

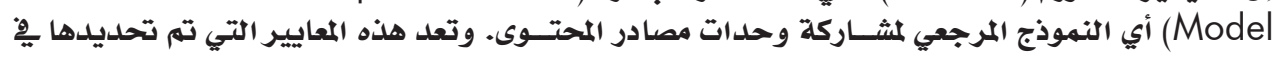

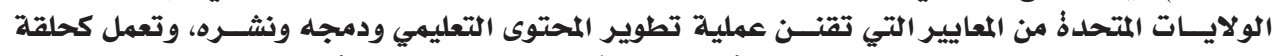

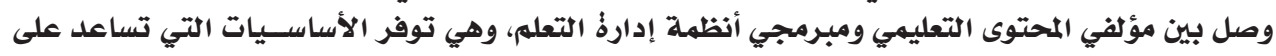

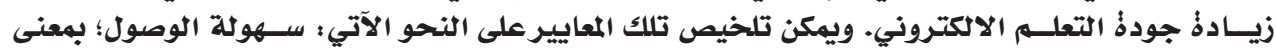

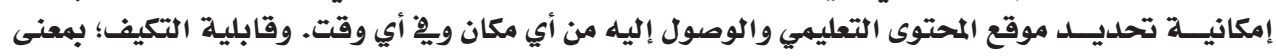

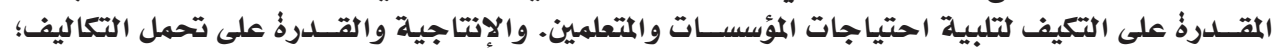

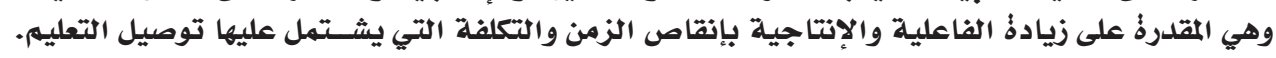

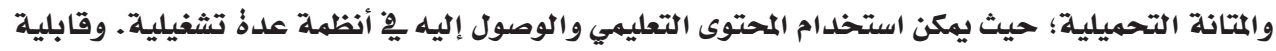

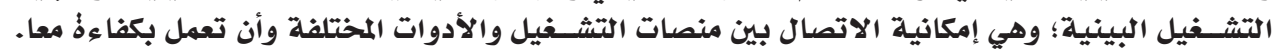

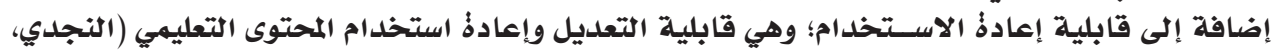
.)(2012

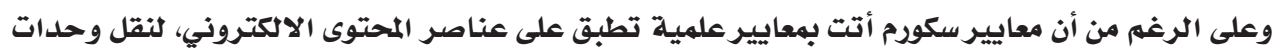

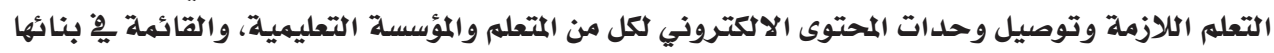

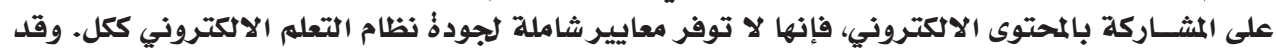

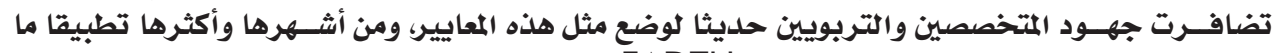

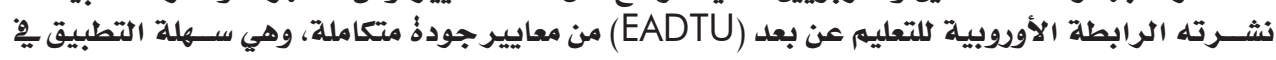

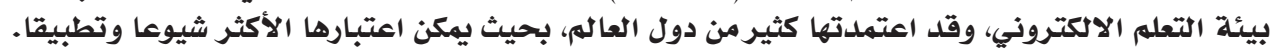


موسى خليل عودة: عبير محمد الوحيلي

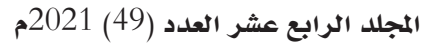

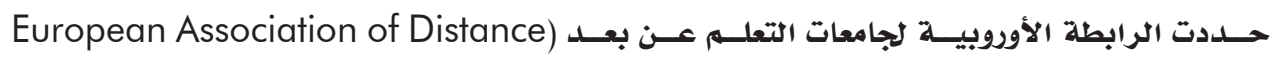
فeaching Universities

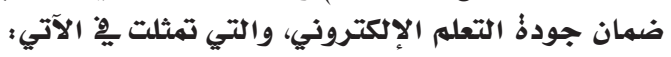

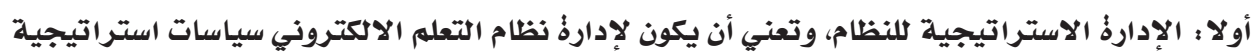

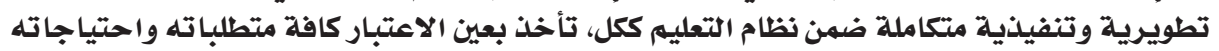

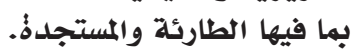

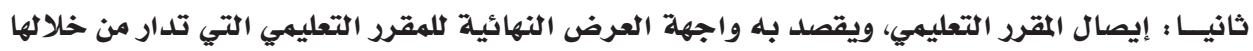

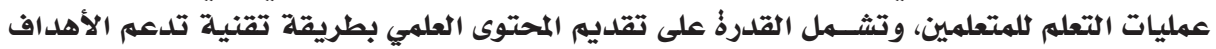

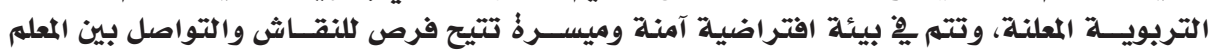

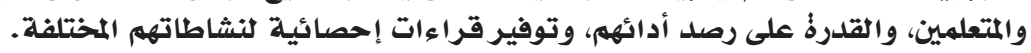

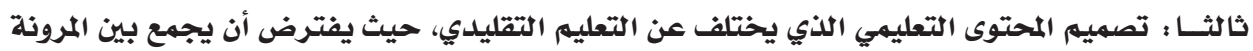

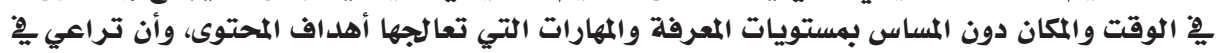

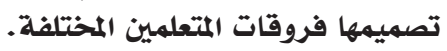

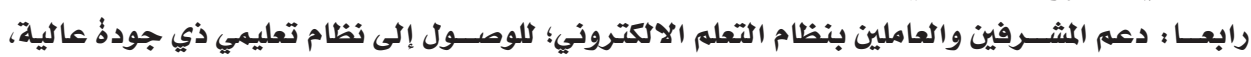

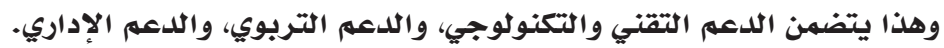

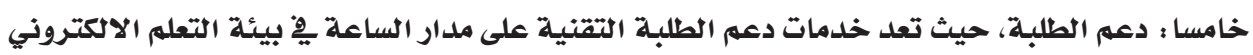

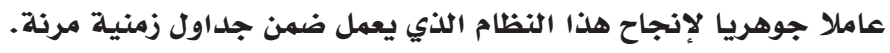

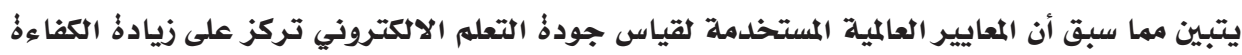

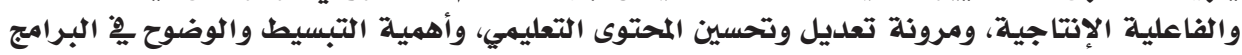

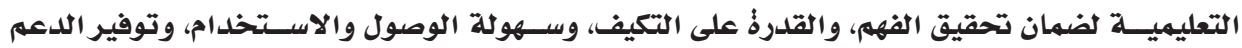

لأقطاب العملية التعليمية. الدراسات السابقة:

أولا : دراسات التي تناولت معايير لجودةٌ التعله الإكتروني:

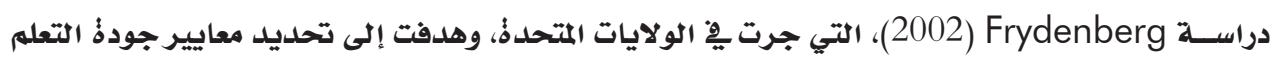

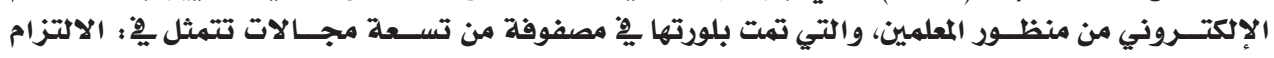

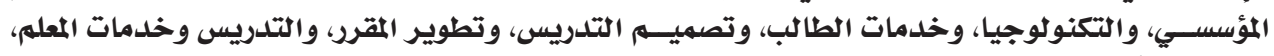

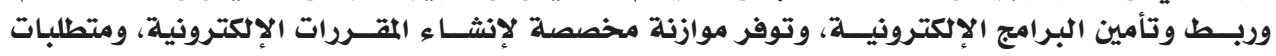

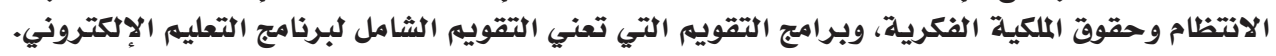

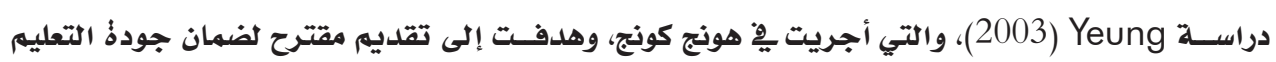

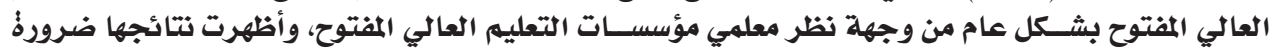

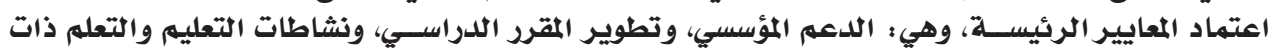

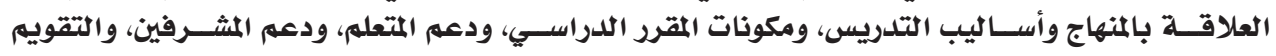
الدوري لنظام التعليم الإلكتروني.

دراسة Barker (2002) التي قدمت دليلا للمعايير الكندية للتعله الإكتروني، والتي اشتملت على ثلاثة

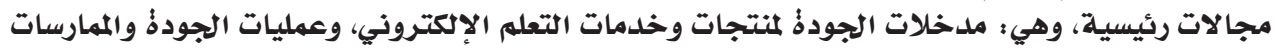

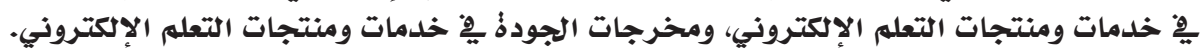

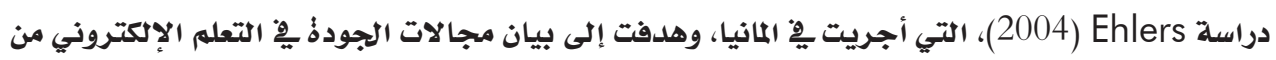




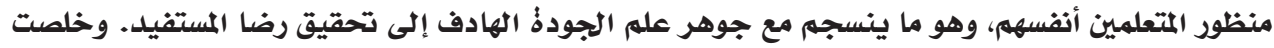

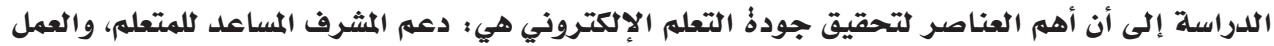

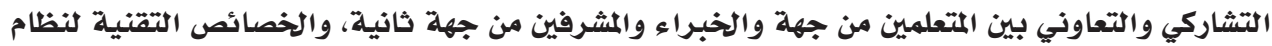

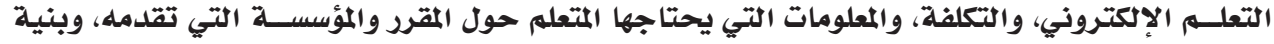

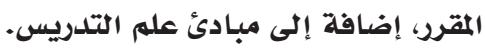

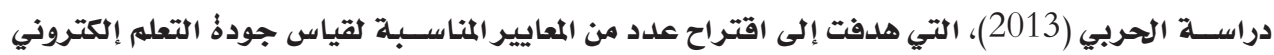

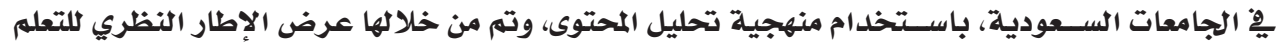

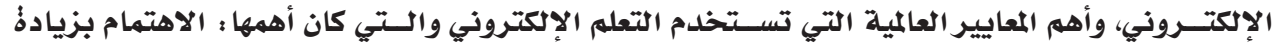

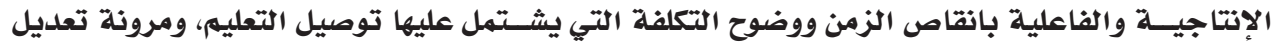

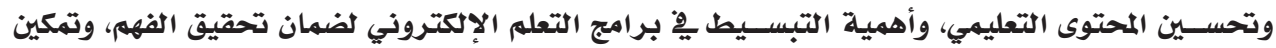

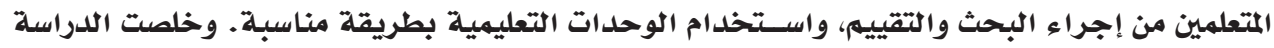

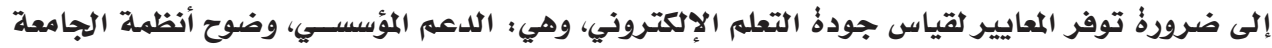

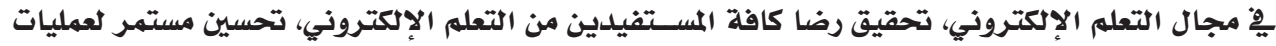

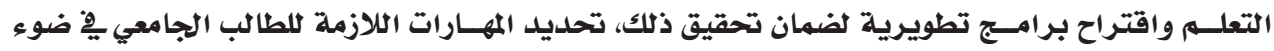

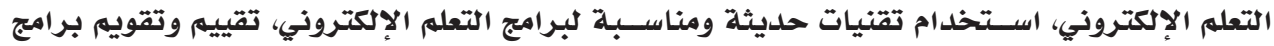

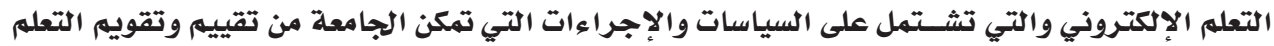

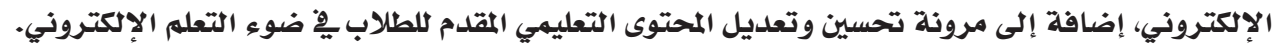

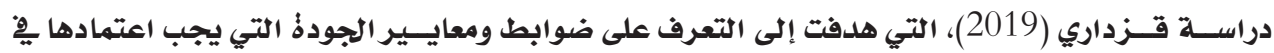

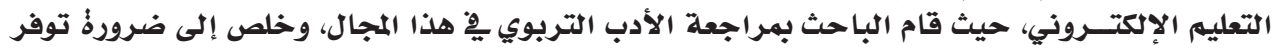

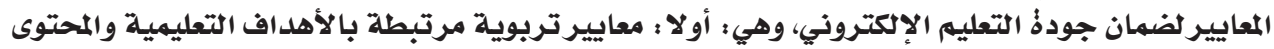

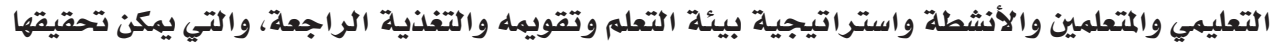

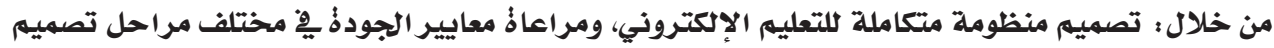

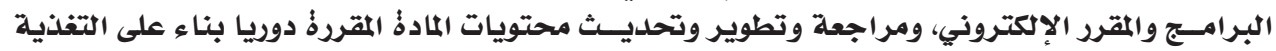

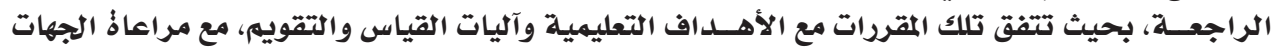

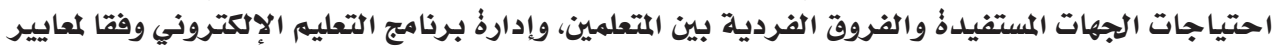

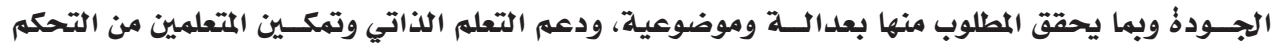

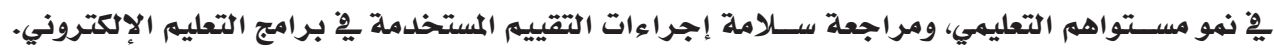

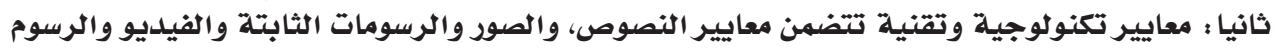

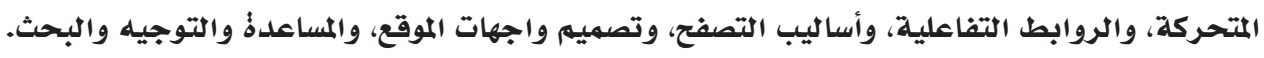

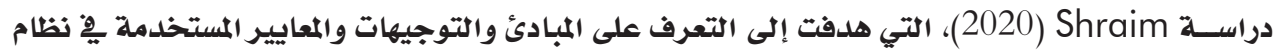

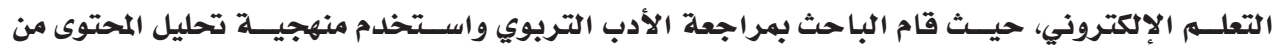

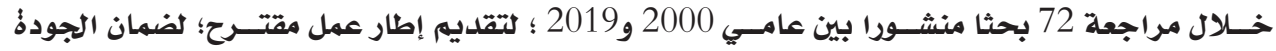

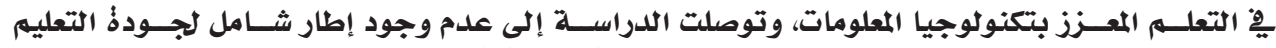

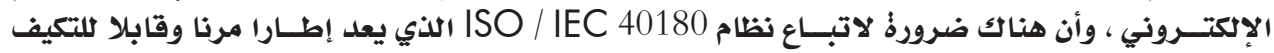

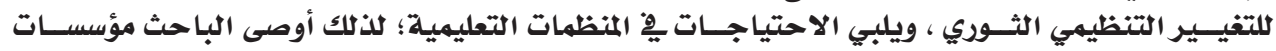

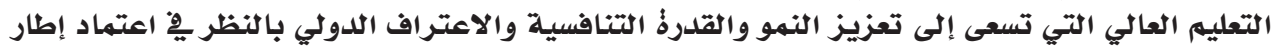
ISO / IEC 40180 
ثانيا : دراسات التي تناولت واقع تطبيق معايير جودذُ التعله الإكتروني:

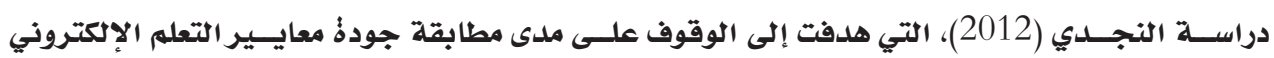

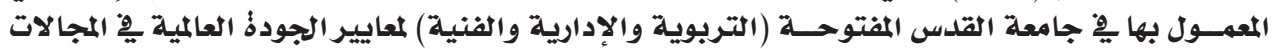

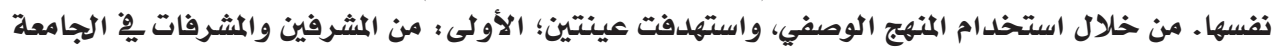

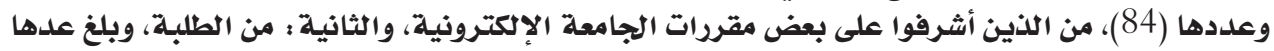

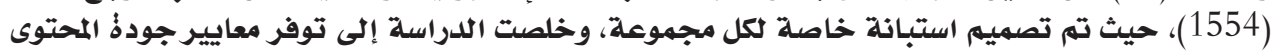

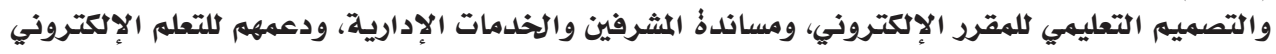

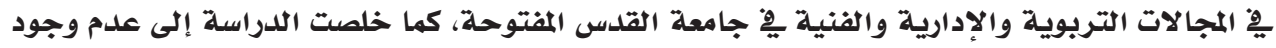

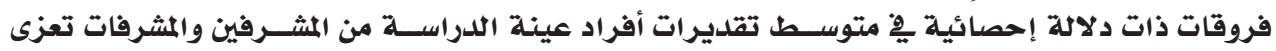

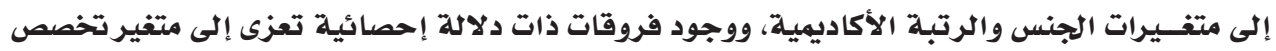
المشرف.

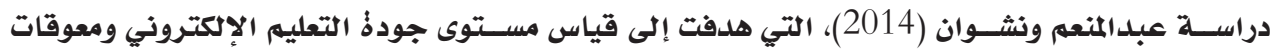

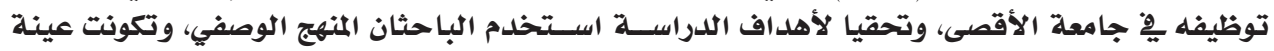

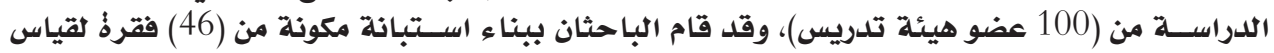

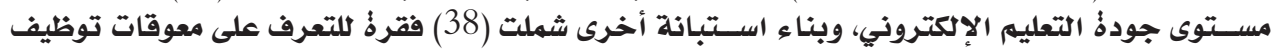

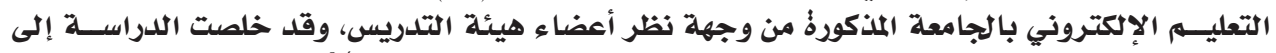

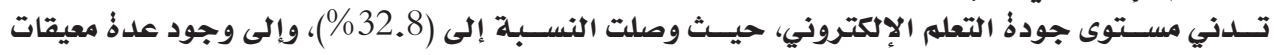

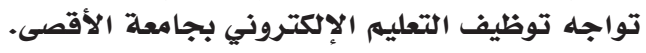

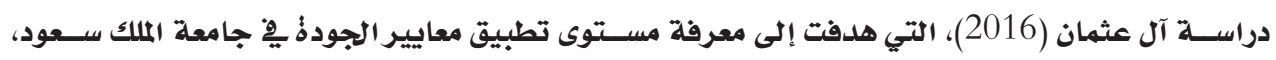

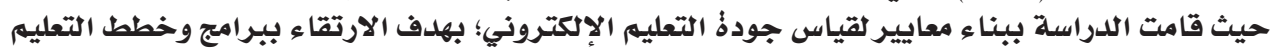

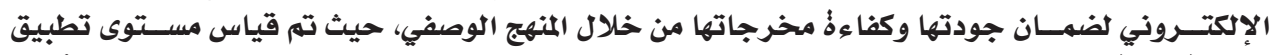

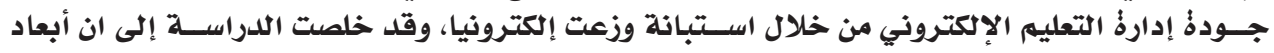

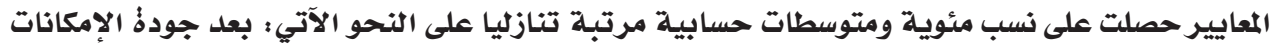

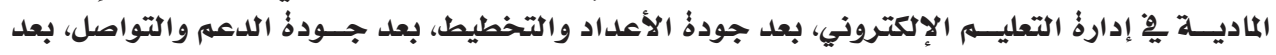

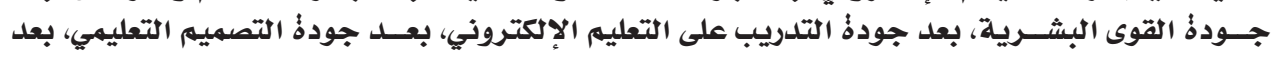

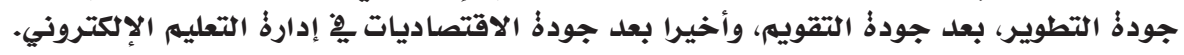

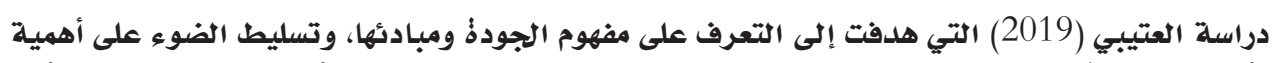

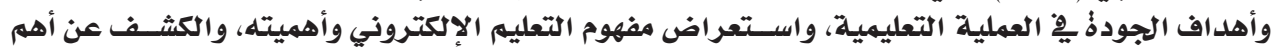

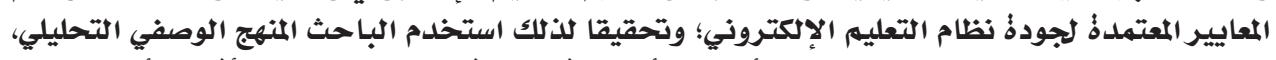

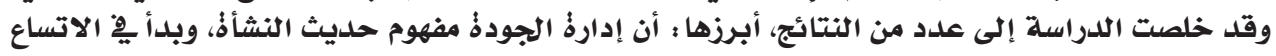

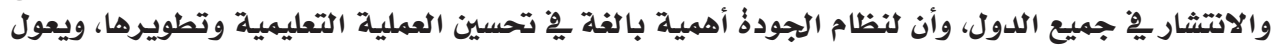

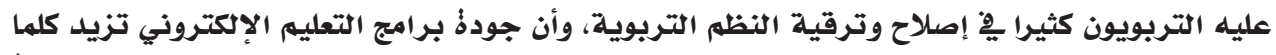

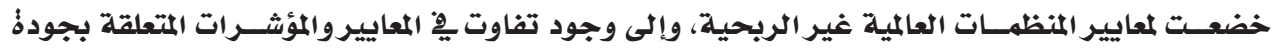

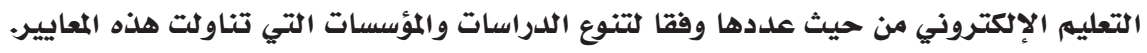
دراسة الرشيدي (2020) التي هدفت إلى التعرف على درجة توظيف التعلم الإلكتروني يِّ جامعة الكويت

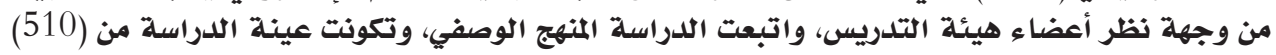

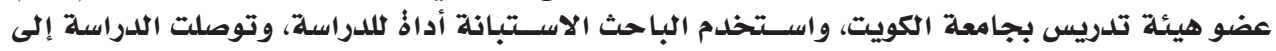

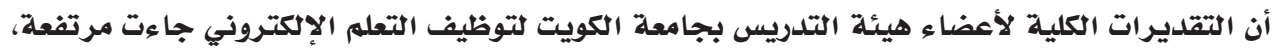

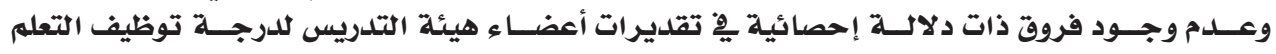

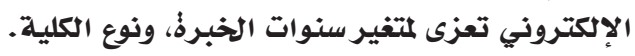




\section{التعقيب على الدراسات السابقة:}

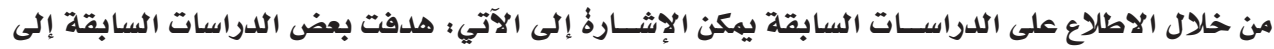

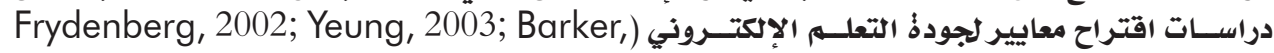
تمبيس 2002; Ehlers, 2004

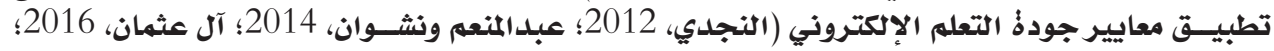

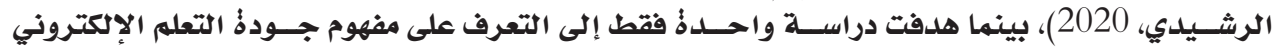

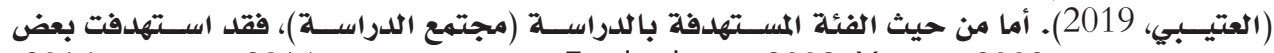

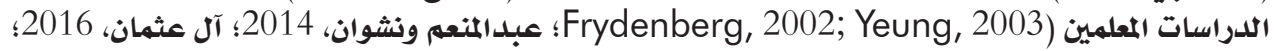

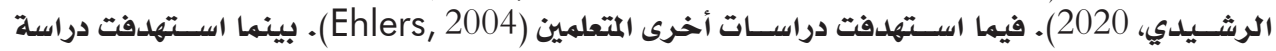

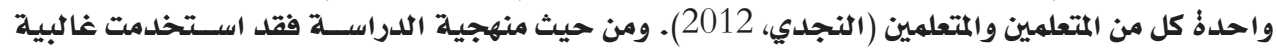

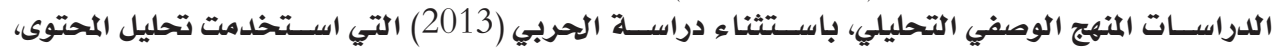

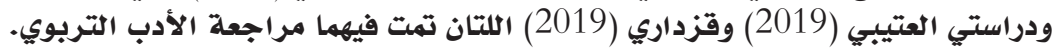

أوجه الشبه والاختلاف بين الدراسة الحالية والدراسات السابقة : وفئل

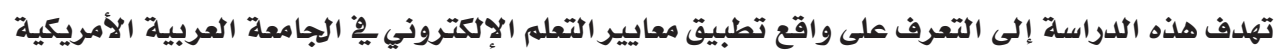

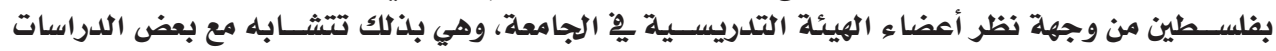

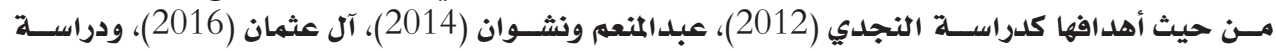

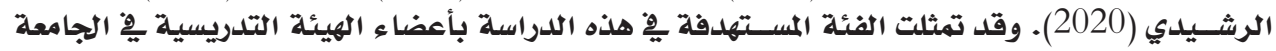

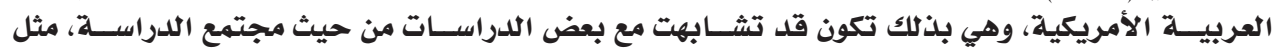

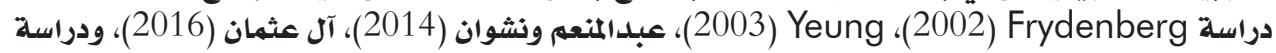

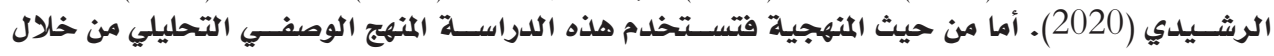

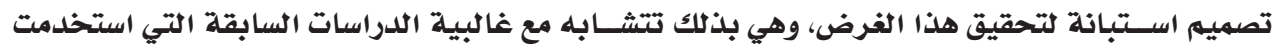

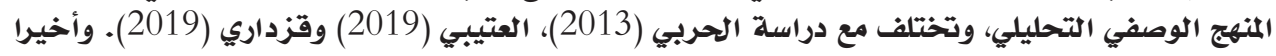

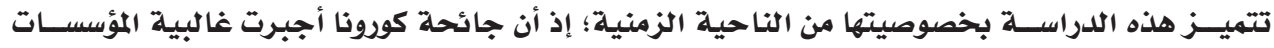

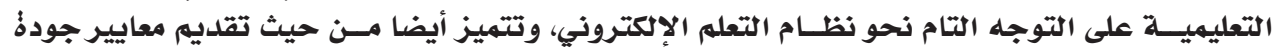

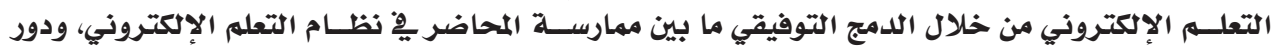

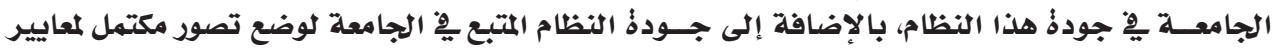

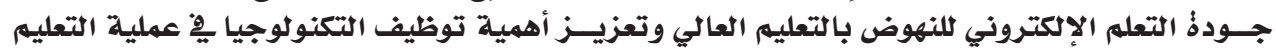
والتعلم.

\section{ملثكلة الدراسة:}

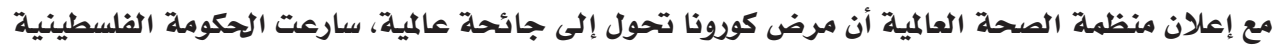

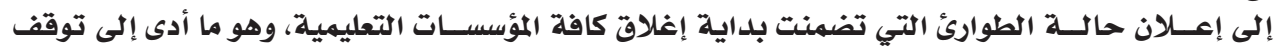

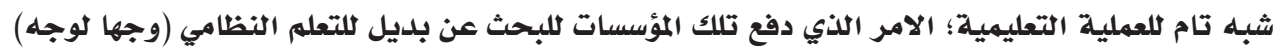
واللجوء إلى نظام التعلم الالكتروني.

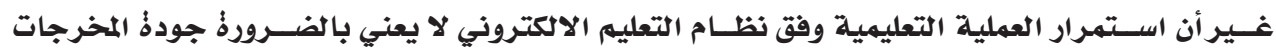

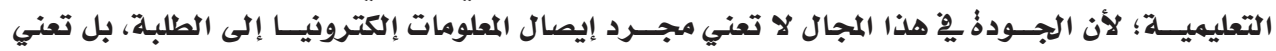

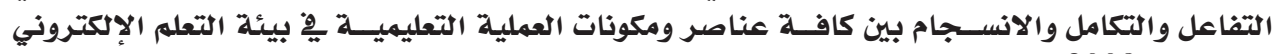

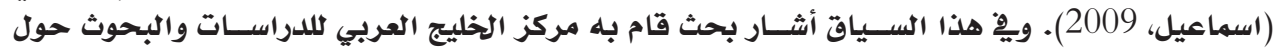

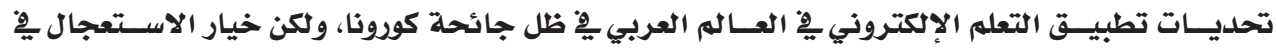

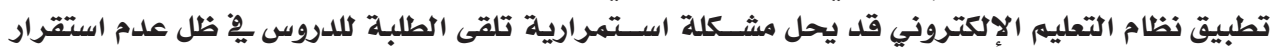

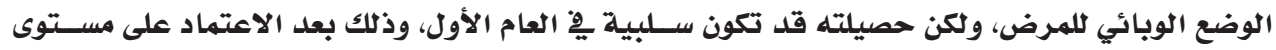


موسى خليل عودة: عبير محمد الوحيدي

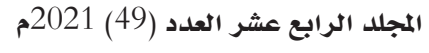

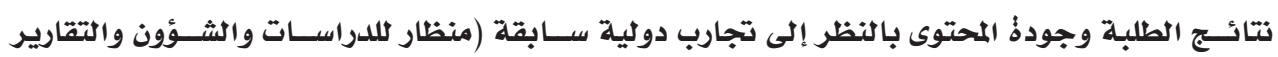
السياسية، 2021).

وبِّ السياق ذاته خلصت دراسة حديثة حملت عنوان "التعليه الإلكتروني فِ الجامعات الفلسطينية وتأثيره

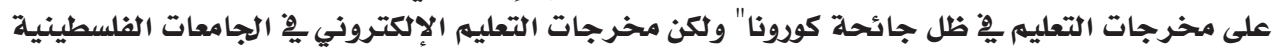

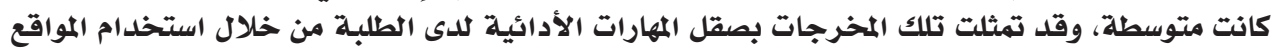

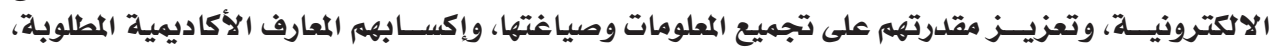

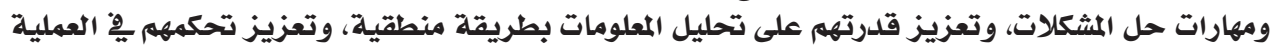

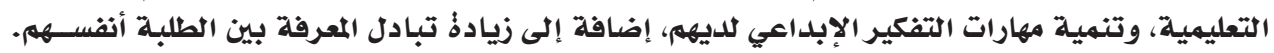

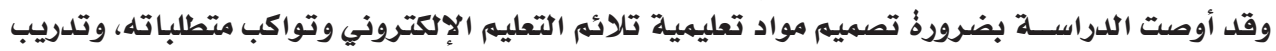

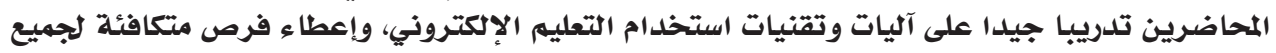

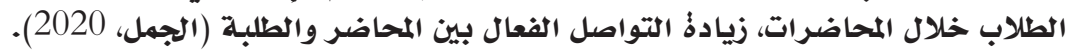

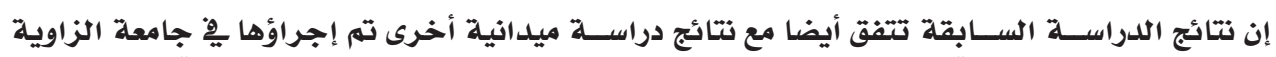

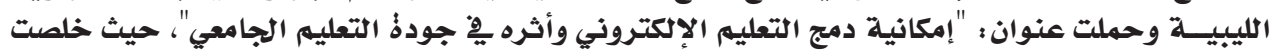

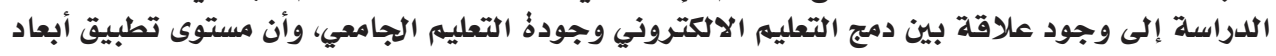

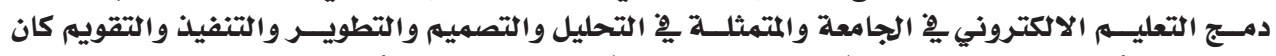

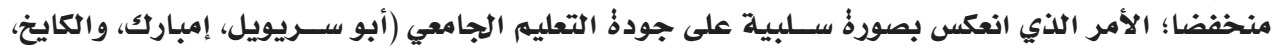

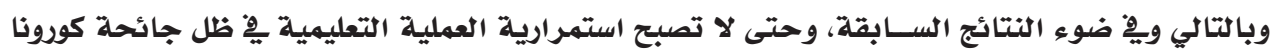

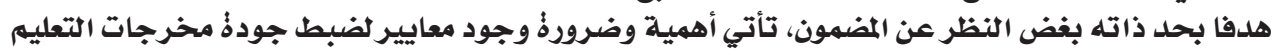

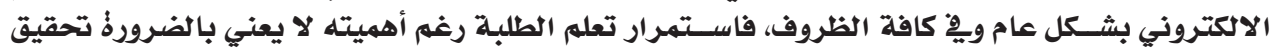

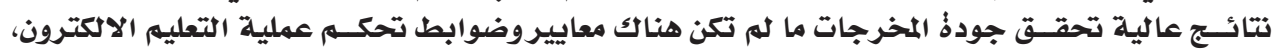

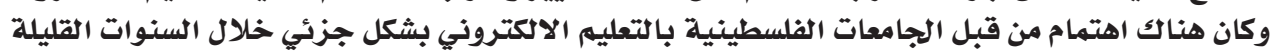

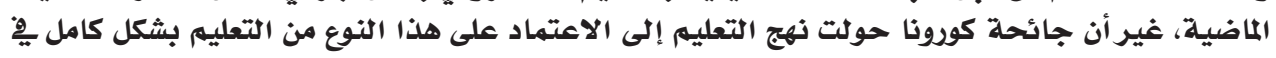

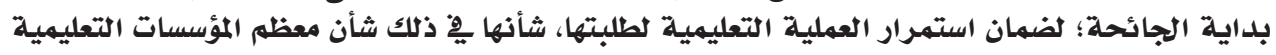

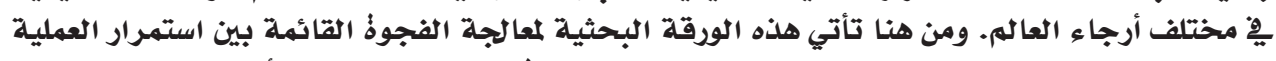

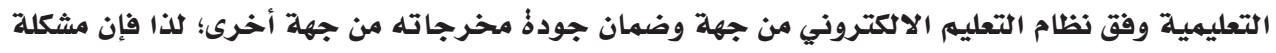

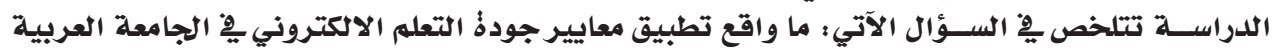

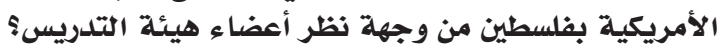

$$
\text { أهداف الحدرافة الدراسة إلى الآتي: }
$$

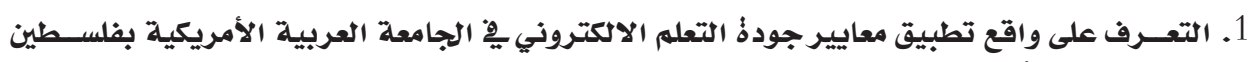

من وجهة نظر أعضاء هيئة التدريس.

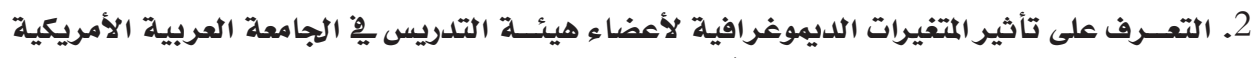

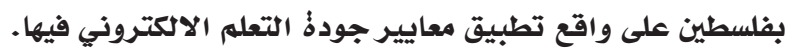

أسئلة الدراسة: ماسف

1. ما واقع تطبيق معايير جودذٌ التعله الاكتتروني يِ الجامعة العربية الأمريكية بفلسـطين من وجهة

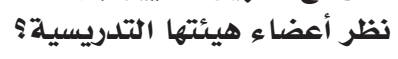

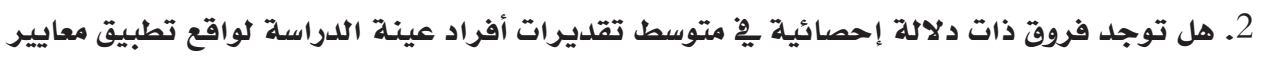

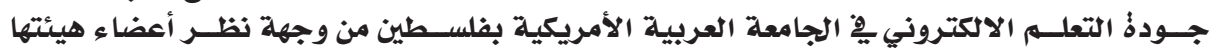

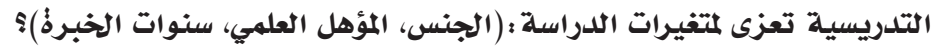




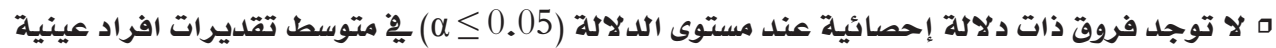

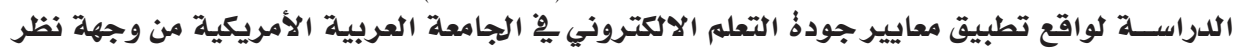
أعضاء هيئة التدريس تعزى لمتفير الجيق معاير جودة الجنس.

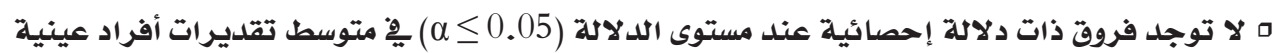

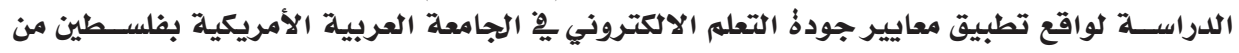

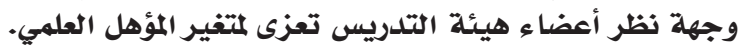

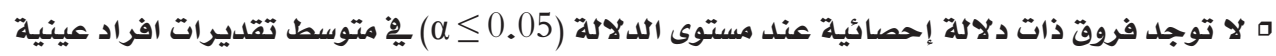

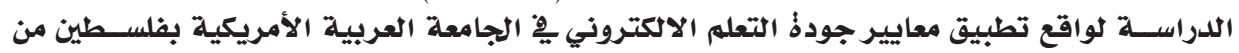

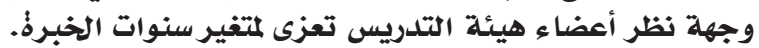

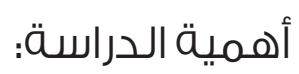

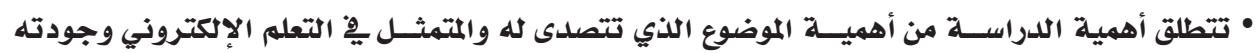

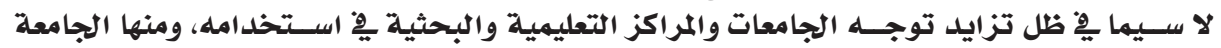

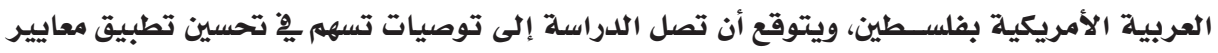

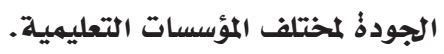

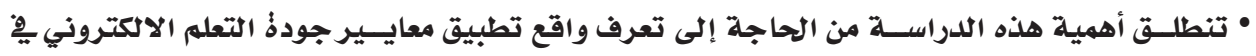
الجامعة العربية الأمريكية بفلسطين.

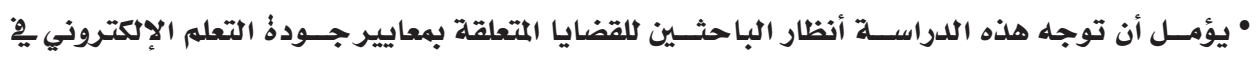

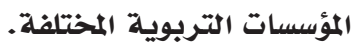
• قد تشكل هذه الدراسة قاعدذٌ معرفية لدراسات علمية لاحقة، خاصة بِّفة ضوء تنامي الحاجة للتعلم الاكتروني. • يمكن تقديم نتائج هذه الدراسة وتوصياتها لصناع القرار ثلاستفادةٌ منها واتخاذ القرارات المناسبة يِّة ضوء نتائجها.

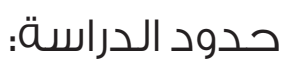

< الحلدود المكانية : اقتصر تطبيق الدراسة على الجامعة العربية الأمريكية - فلسطين.

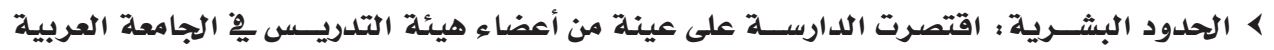
الأمريكية بفلسطين. \ الحدود الزمانية : الفصل الدراسي الأول للعام (2020-2021).

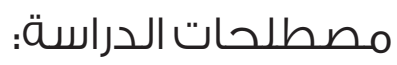

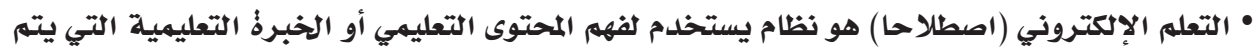

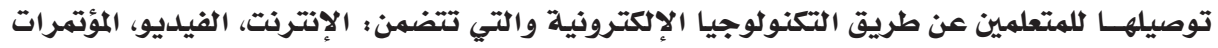

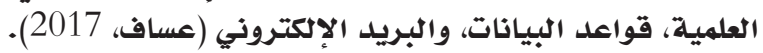

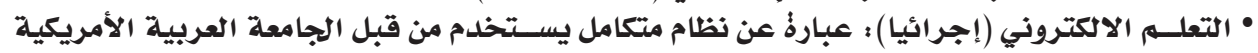

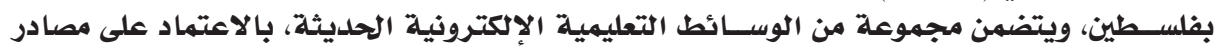

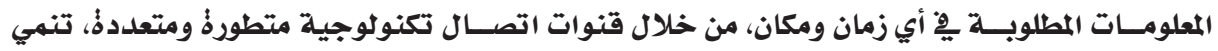

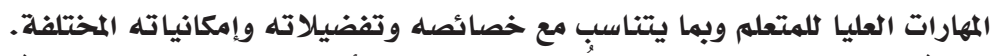

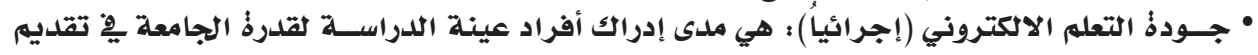

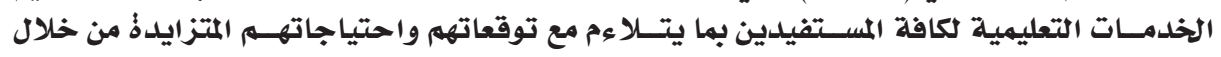

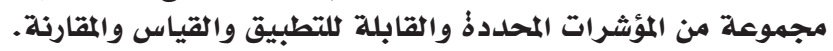


موسى خليل عودةٌ عبير محمد الوحيدي

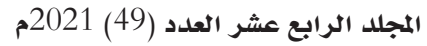

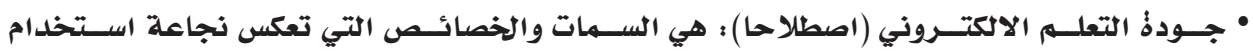

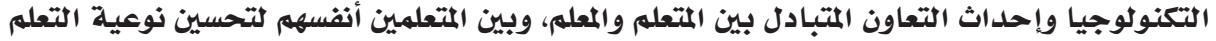
(النجدي، 2012).

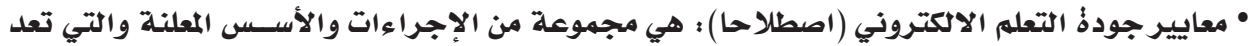

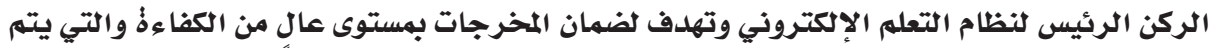

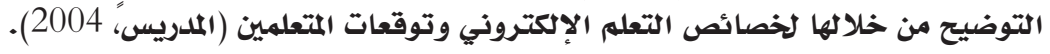

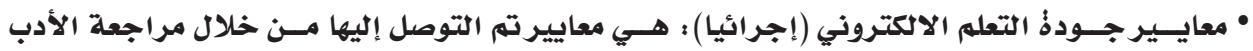

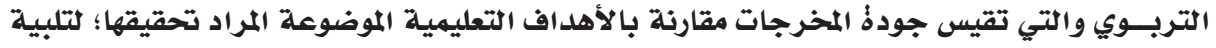

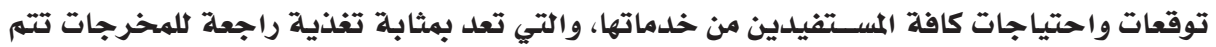
من خلالها عمليات التقييم والتقويه.

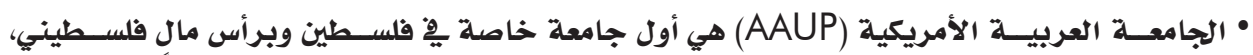

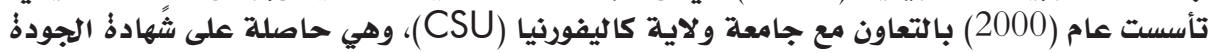

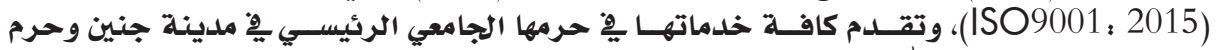
الجامعة ِِِ مدينة رام الله (فلسطين). منهجية الدراسة وإجـراءاتها: منهج الدراسة ؛

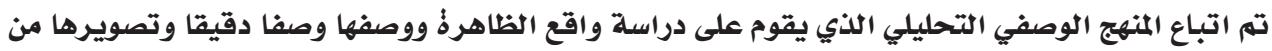

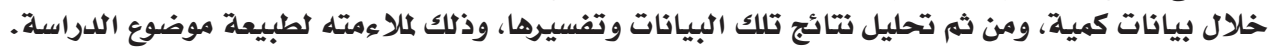
المجتهع وعينة البحث :

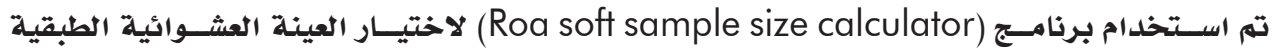

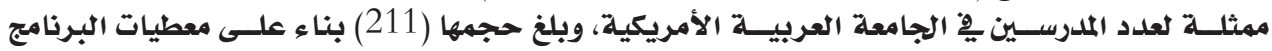

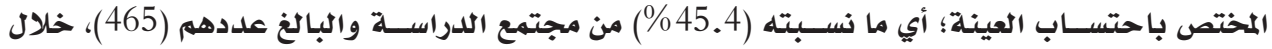

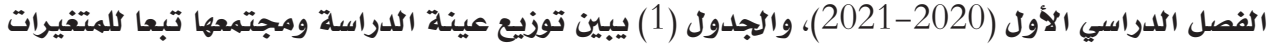

جدول (1): توزيع عينة الدراسة بحسب متغيراتها المستقلة

\begin{tabular}{|c|c|c|c|c|}
\hline النسبة المئوية \% & العينة & المجتهع & التصنيف & المتغير \\
\hline 67 & 142 & 310 & ذكر & الجنس \\
\hline 33 & 69 & 155 & أنثى & \\
\hline 33 & 70 & 119 & ماجستير & المؤهل العلمي \\
\hline 67 & 141 & 346 & دكتوراه & \\
\hline 35 & 73 & 170 & أقل من 5 سنوات & الخبرة: \\
\hline 39 & 82 & 155 & 5 سنوات - أقل من 10 سنوات & \\
\hline 26 & 56 & 140 & أكثر من 10 سنوات & \\
\hline 100 & 211 & 465 & المجهوع & \\
\hline
\end{tabular}

أداذٌ الدراسلة :

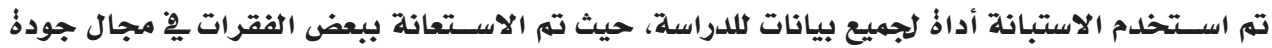

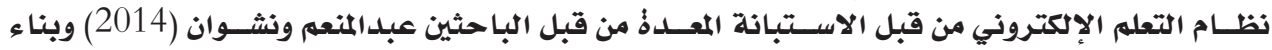

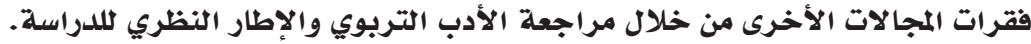




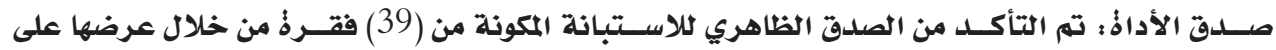

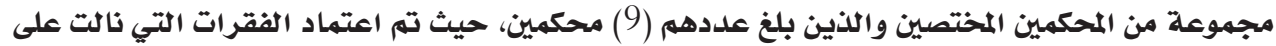

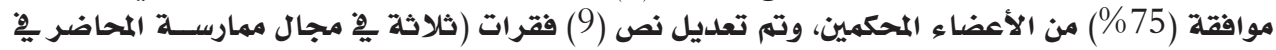

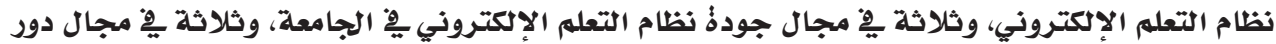

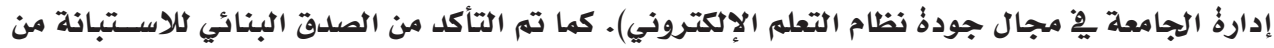

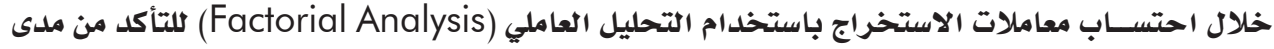

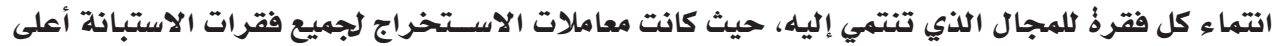

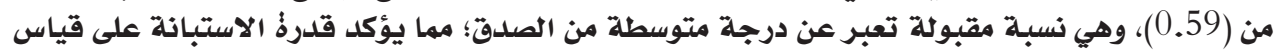

ما وضعت لقياسه ودقة وصلدق بنائها.

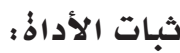

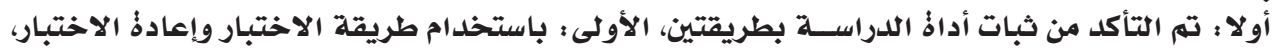

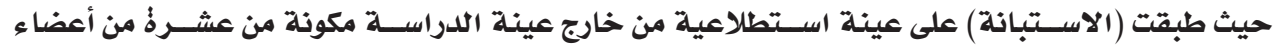

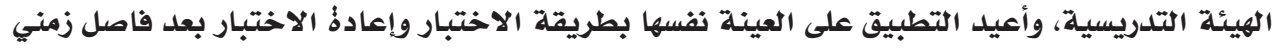

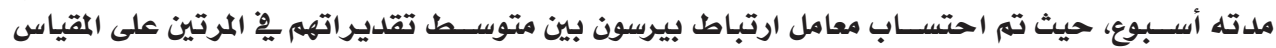

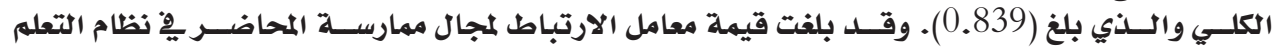

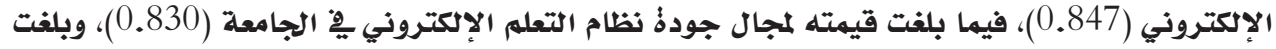

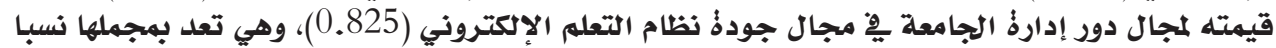

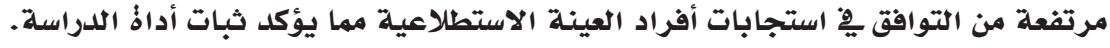

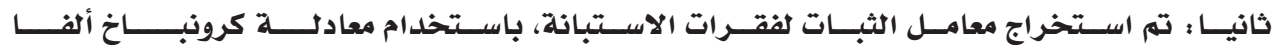
(Cronbach Alpha)

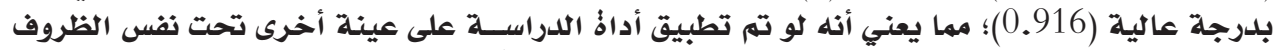

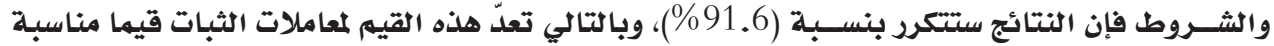
وتفي بأغراض البحث العلمي.

جدول (2): معاملات الثبات

\begin{tabular}{|c|c|c|c|}
\hline معامل الثبات بطريقة كرونباخ ألفا & عدد الفقرات & المجال & رقم المحور \\
\hline 0.772 & 12 & ممارسة المحاضر ٍِِ نظام التعله الإلكتروني & المجال الأول \\
\hline 0.859 & 12 & مجال جودذُ نظام التعلم الإكتروني & 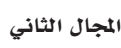 \\
\hline 0.875 & 15 & دور إدارةٌ الجامعة بِّ مجال جودذُ نظام التعلم الإلكتروني & 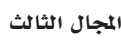 \\
\hline 0.916 & 39 & معامل الثبات الكلي & \\
\hline
\end{tabular}

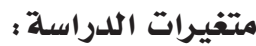

• المتغيرات المستقلة : الجنس وله الديرات فئتان (ذكر، أنثى)، المؤهل العلمي وله فئتان (ماجستير، دكتوراه)، سنوات

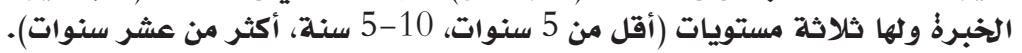

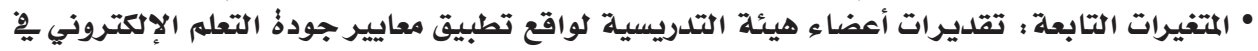
الجامعة العربية الأمريكية بفلسطين.

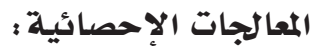

1. التكرارات والمتوسطات الحسابية، والانحرافية الاتات المعيارية؛؛ لتقدير الوزن النسبي لمجالات الاستبانة.

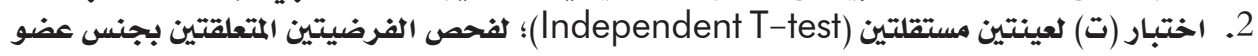
هيئة التدريس، ومؤهله أعينتين العلمي.

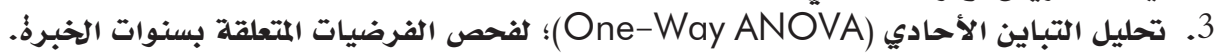

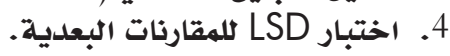
5. معادلة كرونباخ ألفا (Cronbach's Alpha)؛ لحساب الاتساق الداخلي لفقرات أداذّ الدراسة. 
موسى خليل عودة: عبير محمد الوحيدي

المجلد الرابع عشر العدد (49) 2021م عوديل مدوديل

\begin{tabular}{|c|c|c|c|c|c|}
\hline منخفض جدا & منخفض & متوسط & مرتفع & مرتفع جدا & درجة الاستجابة \\
\hline (أقل من 36.0 من 1.80) - & 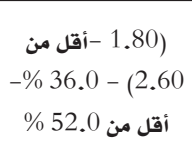 & $\begin{array}{c}\text { (2.60 - أقل من } 50 \\
-3.40 \text { - } 52.0 \\
\text { \% } 68.0\end{array}$ & 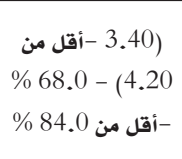 & 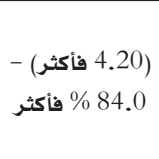 & المدى ل المى \\
\hline
\end{tabular}

\section{نتائج الدراسة:}

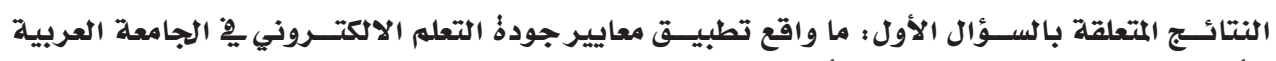

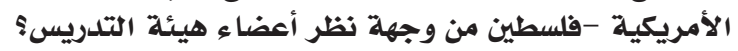

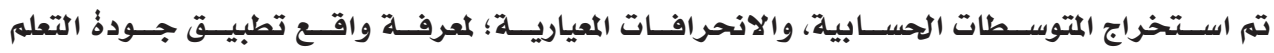

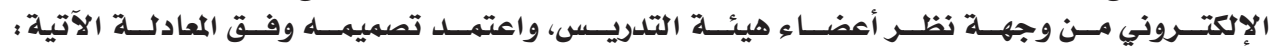

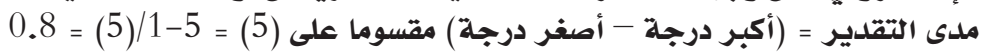

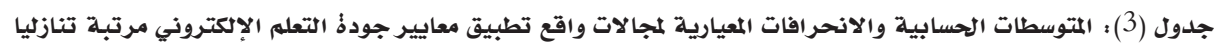

\begin{tabular}{|c|c|c|c|c|}
\hline مستوى التطبيق & الانحراف المعياري & المتوسط الحسابي & 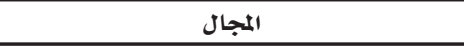 & التسلسل \\
\hline مرتفع & .202 & 4.1043 & ممارسة المحاضر ٍِِ نظام التعلم الاكتتروني & 1 \\
\hline 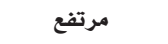 & .365 & 3.8142 & دور إدارةً الجامعة ِِّ جودةٌ نظام التعلم الالكتروني & 3 \\
\hline 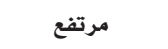 & .466 & 3.6081 & جودةٌ نظام التعلم الاكتروني يِّ الجامعة & 2 \\
\hline مرتفع & 0.56 & 3.8402 & الدرجة الكلية & \\
\hline
\end{tabular}

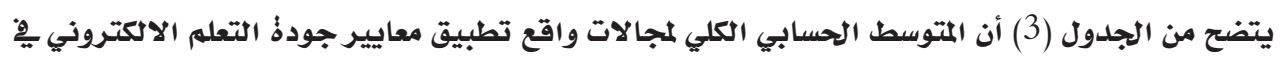

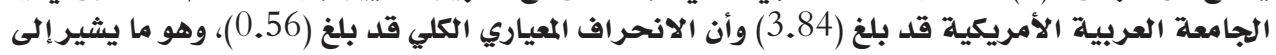

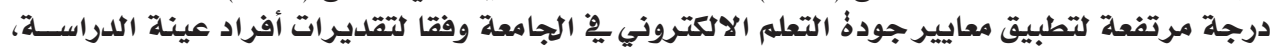

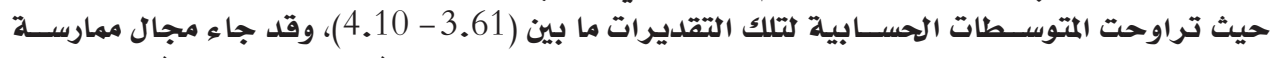

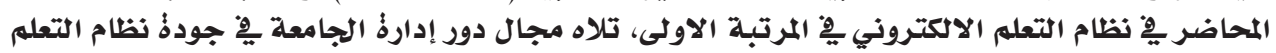

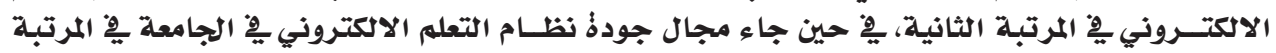

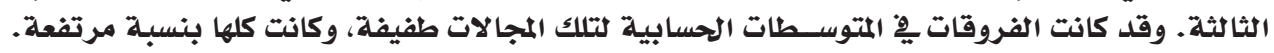

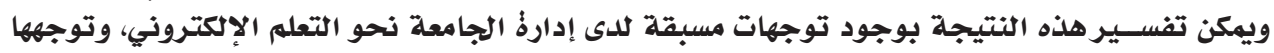

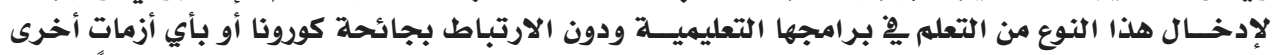

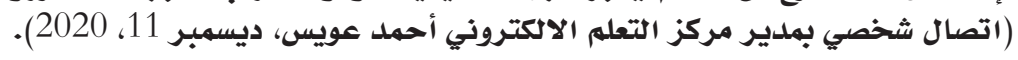

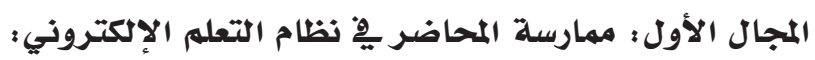
جدول (4) : المتوسطات الحسابية والانحرافات المعيارية لفقرات مجال ممارسة المحاضر يْ نظام التعلم الإكتروني مرتبة تنازليا

\begin{tabular}{ccccc}
\hline & & \\
\hline \\
\hline
\end{tabular}


موسى خليل عودة: عبير محمد الوحيدي

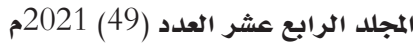

جدول (4) : يتبع

\begin{tabular}{|c|c|c|c|c|}
\hline مستوى التطبيق & الانحراف & المتوسط الحسابي & 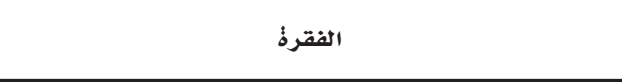 & 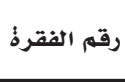 \\
\hline 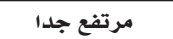 & .732 & 4.22 & أشجع الطلبة على الانخراط يِّ المحاضرات بنظام التعلم الالكتروني. & 5 \\
\hline 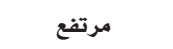 & .788 & 4.13 & أهته بحضور جميع الطلبة للمحاضرات ِِِ نظام التعلم الإكتروني. & 7 \\
\hline 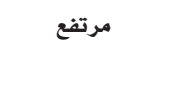 & .838 & 4.13 & 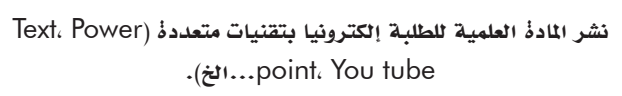 & 2 \\
\hline مرتفع & .798 & 4.10 & أواكب أحدث المستجدات ِِّ نظام التعلم الاكتروني. & 9 \\
\hline 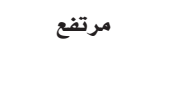 & .913 & 4.07 & أشجع الطلبة باستمرار على استخلام التقنيات الخاصة بنظام التعلم & 4 \\
\hline 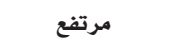 & .955 & 3.87 & أسمح للطلبة بالتواصل يف أي وقت من خلال نظام التعلم الإكتروني. & 12 \\
\hline 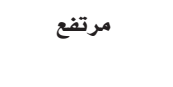 & .944 & 3.86 & $\begin{array}{c}\text { أتواصل مع الطلبة من خلال وسائط التعلم الإلكتروني المتعددة:.Facebook، Whats ap، Zoom) } \\
\text { (....الخخ). }\end{array}$ & 3 \\
\hline 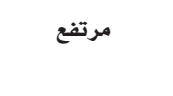 & .788 & 3.69 & أسعى لابتكار أساليب جديدة لتقويم تعلم الطلبة يِّ نظام التعلم & 11 \\
\hline 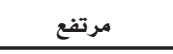 & .202 & 4.10 & الدرجة الكلية & \\
\hline
\end{tabular}

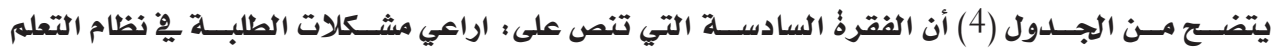

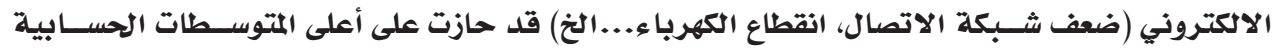

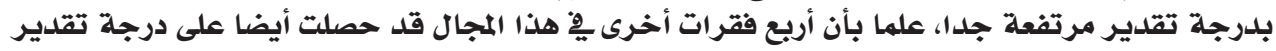

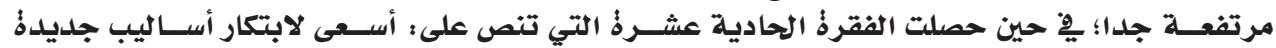

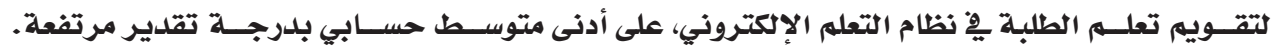

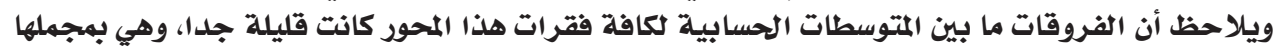

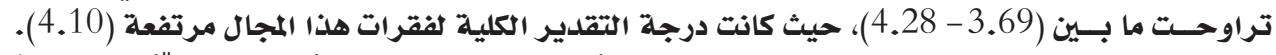

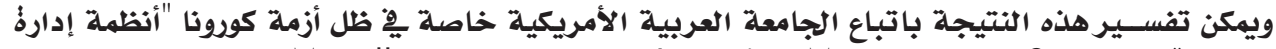

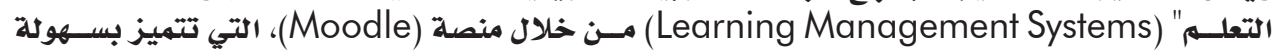

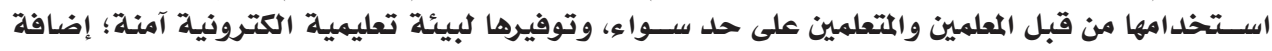

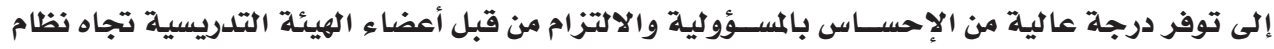

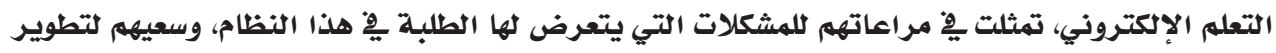

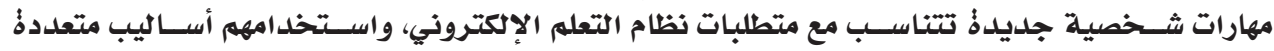

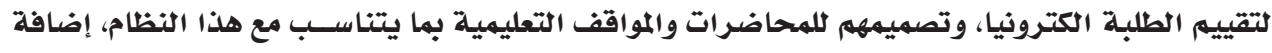

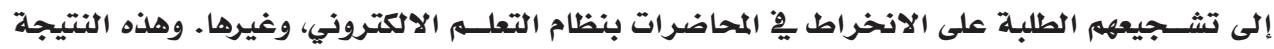

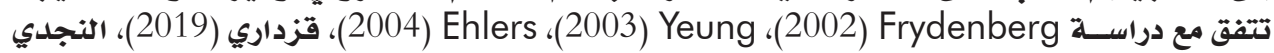

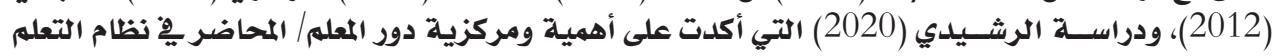

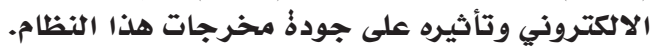

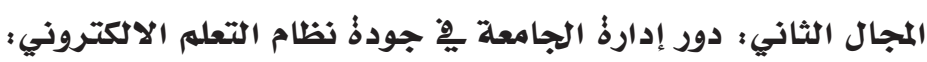
جدول (5) : المتوسطات الحسابية والانحرافات المعيارية فقرات مجال دور إدارةٌ الجامعة يِ جودةٌ نظام التعلم الاكتروني مرتبة تنازليا

\begin{tabular}{|c|c|c|c|c|}
\hline مستوى التطبيق & الانحراف & المتوسط الحسبي & 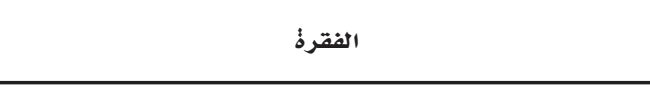 & رقم الفقرة \\
\hline مرتفع جدا & .862 & 4.02 & تسهم الجامعة يِّ تحسين نظام التعلم الإكتروني وزيادةٌ فاعليته. & 26 \\
\hline مرتفع جدا & .918 & 3.92 & تعقد الجامعة دورات تدريبية متنوعة لأعضاء هيئة التدريس لتزويدهم & 28 \\
\hline
\end{tabular}




$$
\text { موسى خليل عودذ؛ عبير محمد الوحيدي }
$$

\begin{tabular}{|c|c|c|c|c|}
\hline مستوى التطبيق & الالحراف & المست المسطي & 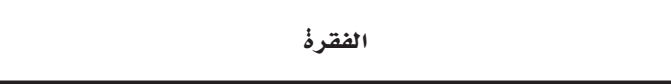 & 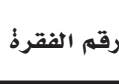 \\
\hline مرتفع جدا & .928 & 3.88 & توفر الجامعة البنية التحتية المطلوبة للتعلم الإكتروني. & 32 \\
\hline مرتفع جدا & .901 & 3.85 & تعمل الجامعة على تطوير نظام التعلم الإكتروني. & 25 \\
\hline مرتفع جدا & 1.004 & 3.84 & تأخذ الجامعة كلاحظات أعضاء هيئة التدريس حول نظام التعلم & 30 \\
\hline 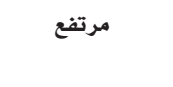 & 1.111 & 3.83 & توفر الجامعة أنظمة الحماية والخصوصية لكافة أطراف العملية التعلمية & 37 \\
\hline 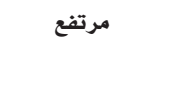 & .901 & 3.82 & 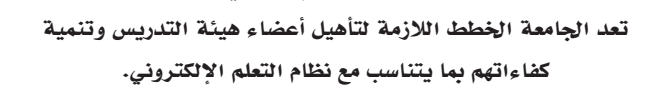 & 35 \\
\hline 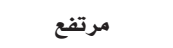 & 1.045 & 3.82 & توفر الجامعة الاشتراكات المطلوبة لقواعد البيانات الاكترونية). & 33 \\
\hline 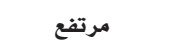 & .945 & 3.79 & تعد الجامعة مقررات دراسية تتناسب مع نظام التعلم الاكتروني. & 27 \\
\hline 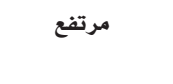 & 1.089 & 3.77 & تراعي الجامعة الأعباء الاكاديمية لأعضاء هيئة التدريس فِّنظام التعلم & 36 \\
\hline 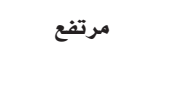 & 1.109 & 3.76 & تعمل الجامعة على توعية أعضاء هيئة التدريس واطلاعهم على المخرجات & 31 \\
\hline 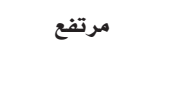 & 1.032 & 3.75 & توفر الجامعة الإمكانيات البشرية المتخصصة لكساعدة أعضاء هيئة & 34 \\
\hline 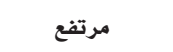 & 1.109 & 3.73 & تعمل الجامعة على تطوير نظام التعلم الإكتروني. & 39 \\
\hline 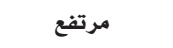 & .993 & 3.72 & تقوم الجامعة بعملية تقويم دورية لقياس فاعلية التعلم الاكتروني. & 29 \\
\hline 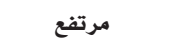 & 1.041 & 3.71 & توفر الجامعة مبرمجين لتصميم مواقع تعليمية الكترونية. & 38 \\
\hline 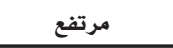 & .365 & 3.8142 & الدرجة الكلية & \\
\hline
\end{tabular}

جدول (5) : يتبع

يتضح من الجدول (5) أن الفقرةٌ (26) التي تنص على : تسهم الجامعة يِّ تحسين نظام التعله الإكتروني

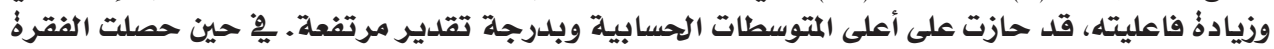

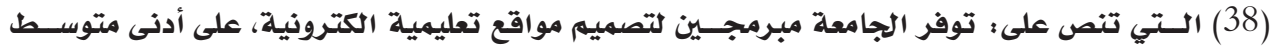

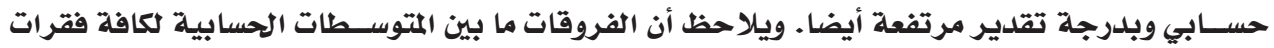

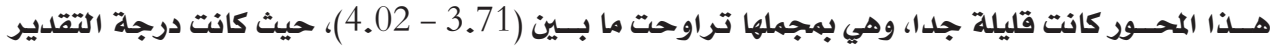

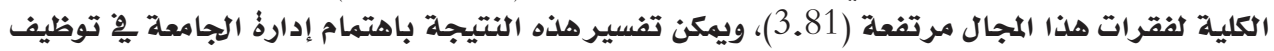

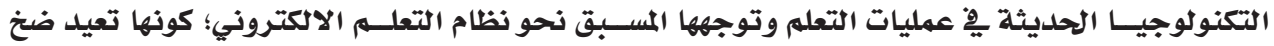

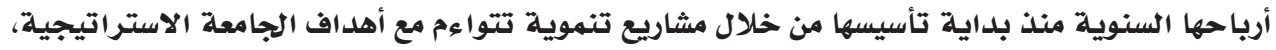

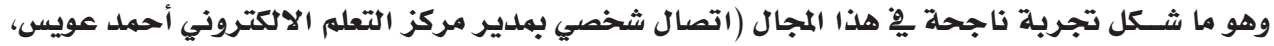

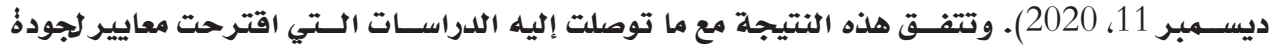

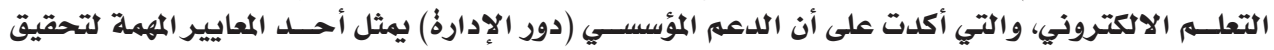

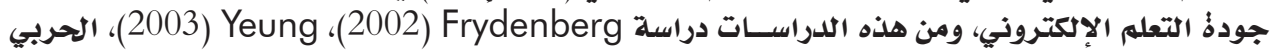
(2013)، ودراسة قزداري (2019).

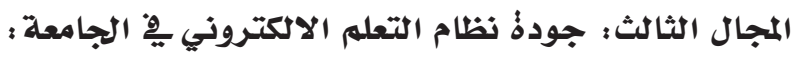

\begin{tabular}{|c|c|c|c|c|}
\hline مستوى التطبيق & الانحراف & المسابي & 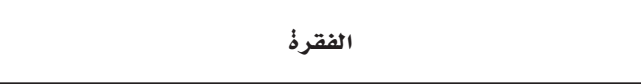 & رقم الفقرة \\
\hline مرتفع جدا & 1.037 & 3.86 & يتناسب محتوى المقررات التعليمية مع نظام التعلم الاكتروني. & 18 \\
\hline مرتفع جدا & .987 & 3.84 & يسمح نظام التعلم الاكتروني يُ التنويع بالوسائل التعليمية المستخدمة & 24 \\
\hline
\end{tabular}
جدول (6) : المتوسطات الحسابية والانحرافات المعيارية لفقرات مجال جودة نظام التعلم الإلكتروني بِّ الجامعة مرتبة تنازليا 
موسى خليل عودة: عبير محمد الوحيدي

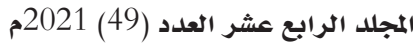

جدول (6) : يتبع

\begin{tabular}{|c|c|c|c|c|}
\hline مستوى التطبيق & الانحراف & المتوسط الحسابي & 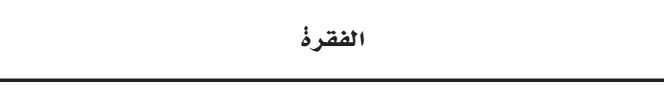 & 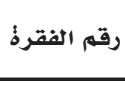 \\
\hline مرتفع جدا & .881 & 3.77 & يسمح نظام التعلم الالكتروني بتكييف المقررات الدراسية وفق المستجدات. & 22 \\
\hline 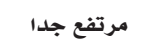 & 1.081 & 3.75 & يساعد التعلم الإكتروني على اكتساب مهارات جديدة. & 14 \\
\hline 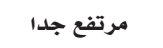 & .980 & 3.71 & يساعد نظام التعلم الاكتروني يِّ ابداع وابتكار أعضاء الهيئة التدريسية. & 23 \\
\hline مرتفع & 1.048 & 3.60 & يحقق نظام التعلم الإكتروني أهداف التعلم المنشودذُ. & 13 \\
\hline 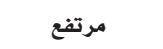 & 1.050 & 3.57 & يحقق التعلم الالكتروني تفاعل الطلبة مع بعضهم البعض. & 17 \\
\hline 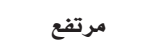 & 1.180 & 3.55 & يمكن ضبط حضور الطلبة ِِّ نظام التعلم الإكتروني. & 16 \\
\hline 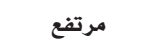 & 1.106 & 3.52 & يتيح نظام التعلم الإكتروني التفاعل ما بين أعضاء الهيئة التدريسية & 20 \\
\hline 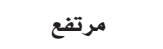 & 1.247 & 3.48 & يراعي التعلم الالكتروني الموضوعية بِّ تقييم الطلبة & 15 \\
\hline 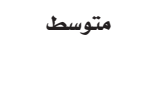 & 1.177 & 3.34 & يقلل نظام التعلم الإكتروني من الضغوط النفسية على أعضاء الهيئة & 19 \\
\hline 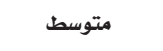 & 1.138 & 3.32 & يؤثر نظام التعلم الاكتروني إيجابا على جودة التعلم. & 21 \\
\hline 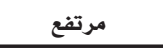 & .466 & 3.6081 & الدرجة الكلية & \\
\hline
\end{tabular}

يتضح من الجدول (6) أن الفقرة (18) التي تنص على : يتناسب محتوى المقررات التعليمية مع نظام التعلم

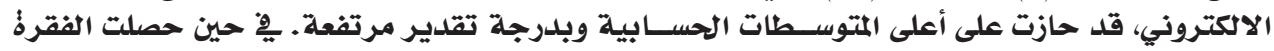

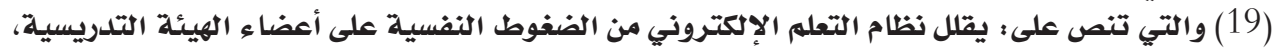

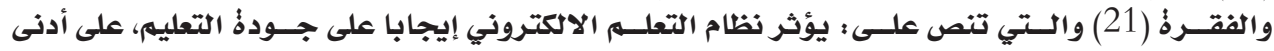

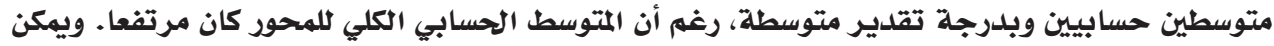

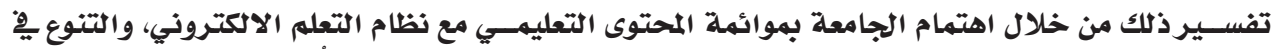

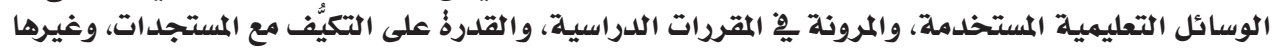

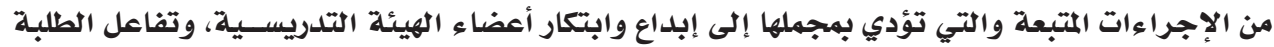

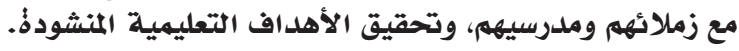

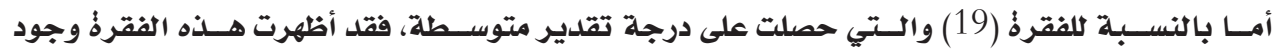

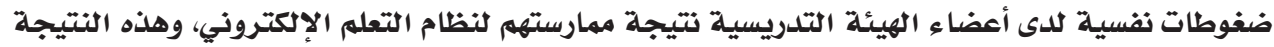

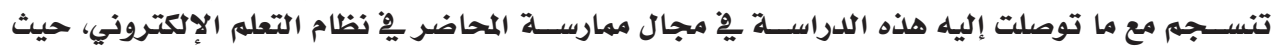

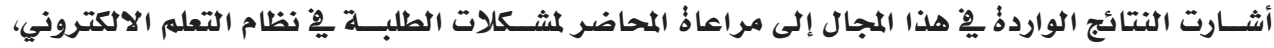

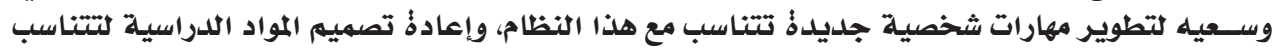

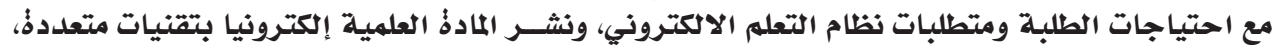

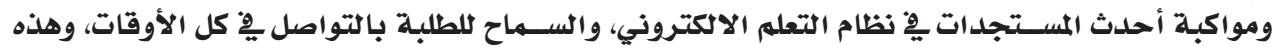

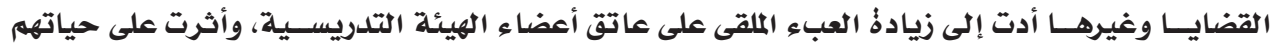

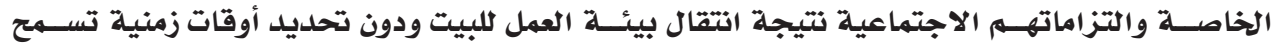
للطلبة بالتواصل من خلالها مع مدرسيهم.

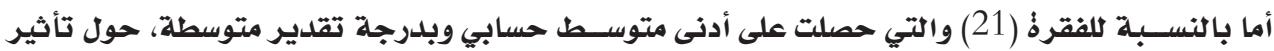

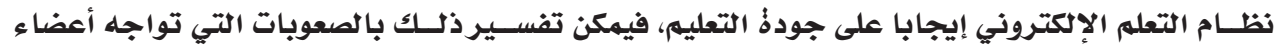

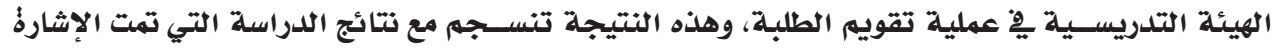

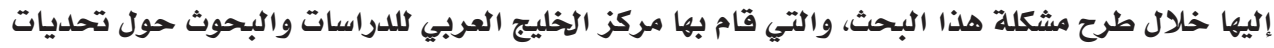

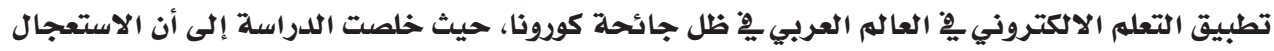

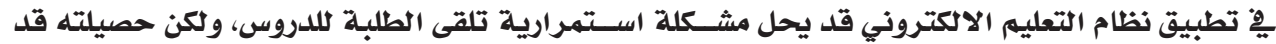

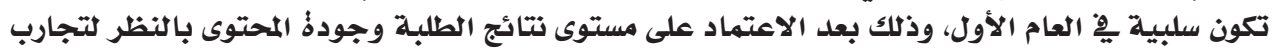
دولية سابقة (منظار للدراسات والشؤون والثاك والتقارير السياسية، 2021). 
موسى خليل عودة: عبير محمد الوحيلي

المجلد الرابع عشر العدد (49) 2021م عودة

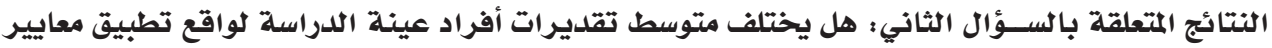

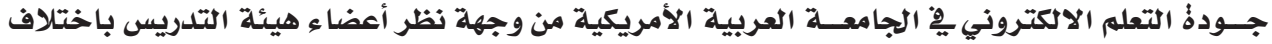

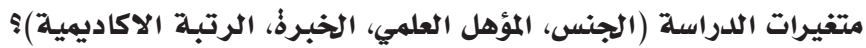
وينبثق عن هذا السؤال الفرضيات الآتية :

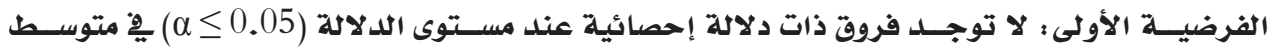

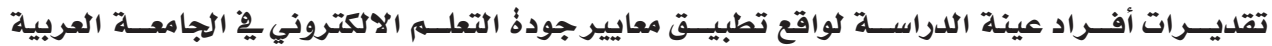

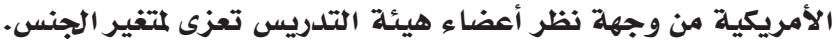
ولفحــص هذه الفرضية، فقد تم اســتخدم اختبـار "ت" لمجموعتين مســتقلتين (Independent t-test)

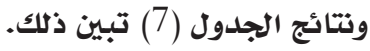

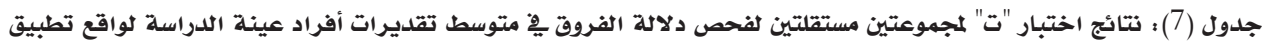

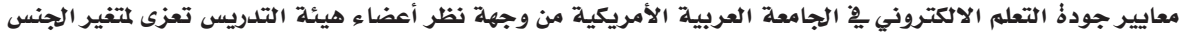

\begin{tabular}{|c|c|c|c|c|c|c|}
\hline \multirow{2}{*}{ مستوى الدلالة } & \multirow{2}{*}{ 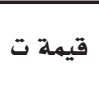 } & \multicolumn{2}{|c|}{ إناث (ن= (69) } & \multicolumn{2}{|c|}{ ذكور (ن=142) } & \multirow{2}{*}{ 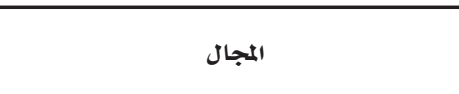 } \\
\hline & & الانحراف & المتوسط & الانحراف & المتوسط & \\
\hline 0.61 & 0.50 & 0.48 & 4.12 & 0.43 & 4.09 & ممارسة المحاضر يْ نظام التعلم الالكتروني \\
\hline$* 0.001$ & 2.44 & 0.54 & 3.95 & 0.61 & 3.74 & دور إدارةٌ الجامعة يِّ جودةٌ نظام التعلم الالكتروني \\
\hline$* 0.00$ & 3.83 & 0.61 & 3.85 & 0.68 & 3.48 & جودةُ نظام التعلم الاكتروني ٍِِ الجامعة \\
\hline$*^{*} 0.003$ & 2.96 & 0.43 & 3.97 & 0.49 & 3.77 & الدرجة الكلية \\
\hline
\end{tabular}

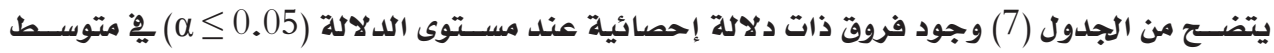

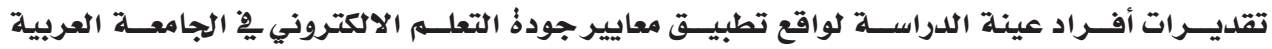

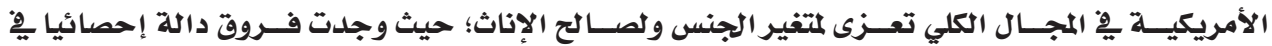

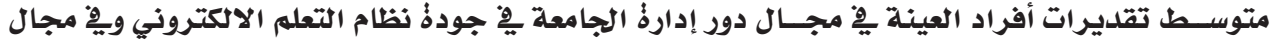

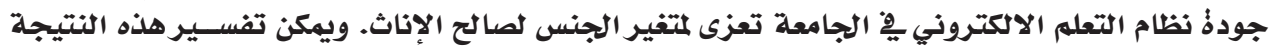

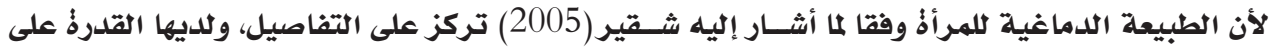

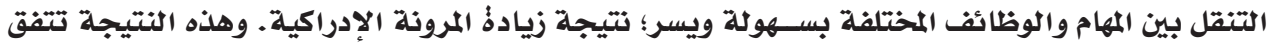

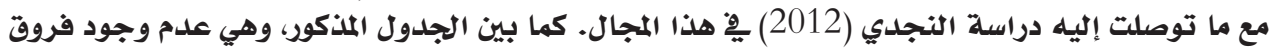

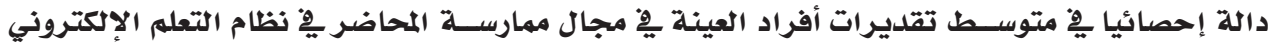

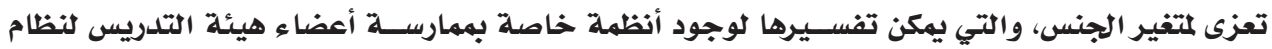

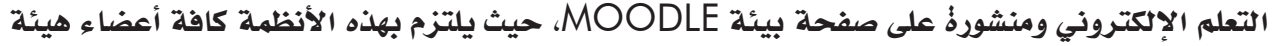

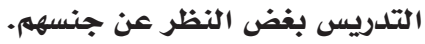

الفرضية الثانية : لا توجد فروق ذات دلالة إحصائية عند مستوى الدلالة (0.05) هِّ متوسط تقديرات

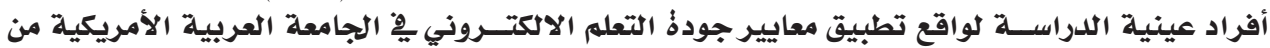

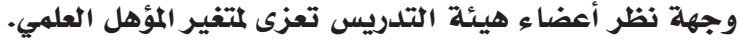

ولفحــص هذه الفرضية، فقد تم اسـتخدم اختبـار "ت" لمجموعتين مسـتقلتين (Independent t-test) ونتائج الجدول (8) تبين ذلك. 
موسى خليل عودة: عبير محمد الوحيليدي

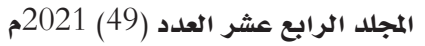

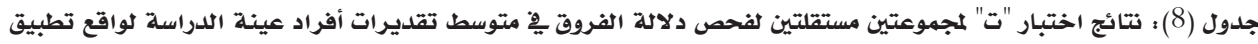

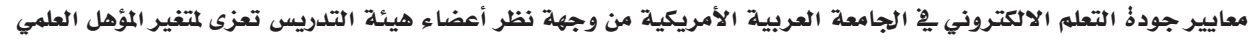

\begin{tabular}{|c|c|c|c|c|c|c|}
\hline \multirow{2}{*}{ مستوى الدلاكل } & \multirow{2}{*}{ قيمة ت ق ق ت } & \multicolumn{2}{|c|}{ دكتوراه (ن=141) } & \multicolumn{2}{|c|}{ ماجستير (ن= } & \multirow{2}{*}{ 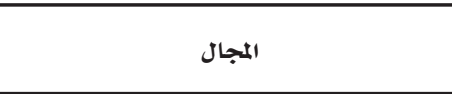 } \\
\hline & & الانحراف & المتوسط & الانحراف & المتوسط & \\
\hline 0.11 & 1.59 & 430. & 4.13 & 0.47 & 4.03 & ممارسة المحاضر بِ نظام التعلم الاكتروني \\
\hline$* 0.00$ & 3.23 & 590. & 3.90 & 0.58 & 3.62 & دور إدارةٌ الجامعة ِِِ جودةُ نظام التعلم الاكتروني \\
\hline 0.10 & 1.61 & 730. & 3.66 & 0.56 & 3.50 & جودة نظام التعلم الاكتروني \\
\hline$* 0.00$ & 2.70 & 490. & 3.90 & 0.43 & 3.71 & الدرجة الكلية \\
\hline
\end{tabular}

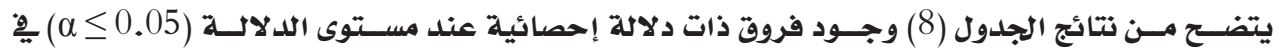

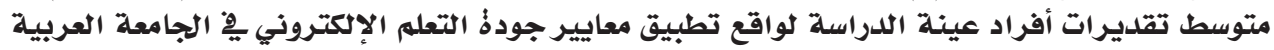

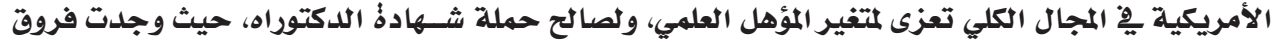

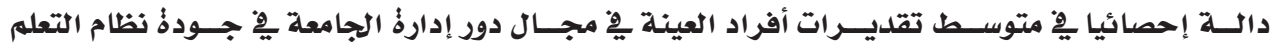

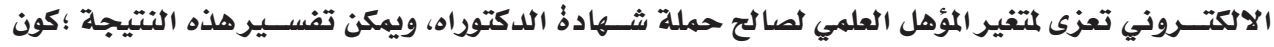

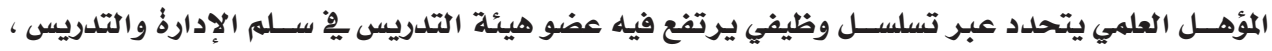

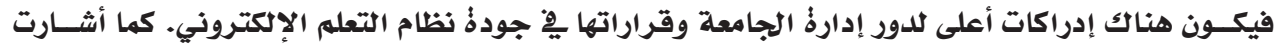

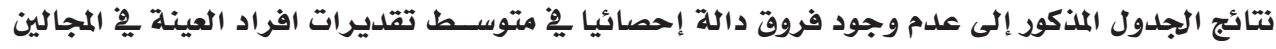

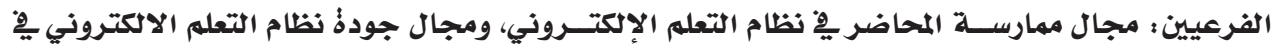

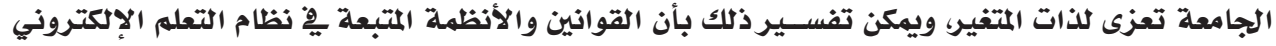

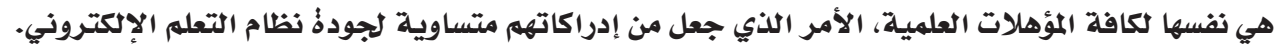
الفرضية الثالثة : لا توجد فروق ذات دلالة إحصائية عند مستوى الدلالة (0.05) فِّ متوسط تقلديرات

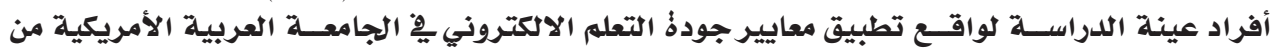

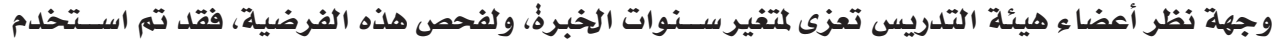

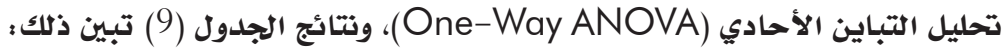

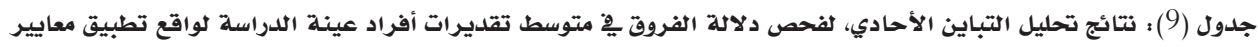

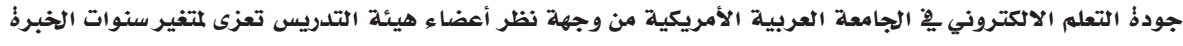

\begin{tabular}{|c|c|c|c|c|c|c|}
\hline مستوى الدلالة & قيمة F & متوسط المربعات & درجات & مجموع المربعات & مصدر التباين & المجال \\
\hline \multirow[t]{3}{*}{0.142} & 1.965 & 0.3935 & 2.000 & 0.787 & بين المجموعات & ممارسة المحاضر بِ \\
\hline & & 0.200 & 208.00 & 41.655 & خلال المجموعات & نظام التعلم الاكتروني \\
\hline & & & 210.00 & 42.442 & المجموع & \\
\hline \multirow[t]{3}{*}{0.004} & 5.576 & 1.948 & 2.000 & 3.8977 & بين المجموعات & دور إدارةً الجامعة \\
\hline & & 0.349 & 208.00 & 72.695 & خلال المجموعات & ِِْ جودةٌ نظام التعله \\
\hline & & & 210.00 & 76.592 & المجموع & الاككتروني \\
\hline \multirow[t]{3}{*}{0.487} & 0.720 & 0.336 & 2.00 & 0.6727 & بين المجموعات & جودةٌ نظام التعلم \\
\hline & & 0.466 & 208.000 & 97.09 & خلال المجموعات & الاكتتروني يِّ الجامعة \\
\hline & & & 210.00 & 97.763 & المجموع & \\
\hline \multirow[t]{3}{*}{0.091} & 2.4237 & 0.562 & 2.00 & 1.124 & بين المجموعات & الدرجة الكلية \\
\hline & & 0.232 & 208.00 & 48.268 & خلال المجموعات & \\
\hline & & & 210.00 & 49.3934 & المجموع & \\
\hline
\end{tabular}

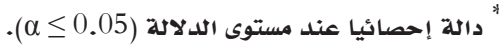


موسى خليل عودة: عبير محمد الوحيلي

المجلد الرابع عشر العدد (49) 2021م عوديل مديل

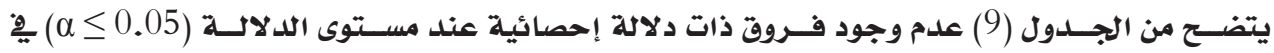

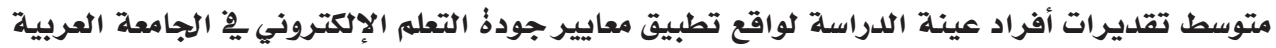

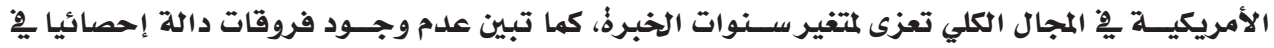

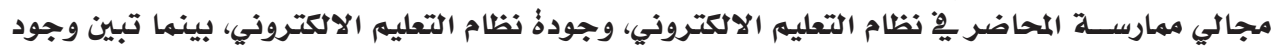

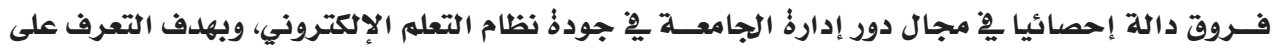

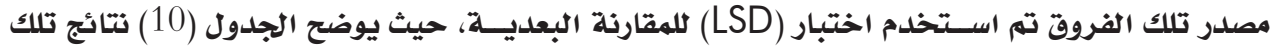

المقارنة.

جلدول (10): نتائج المقارنة البعدية لبيان الفروق مجال دور إدارةٌ الجامعة تعزى لمتغير سنوات الخبرةً

\begin{tabular}{|c|c|c|c|}
\hline أكثر من 10 سنوات & $10-5$ & أقل من 5 سنوات & الخبرة' \\
\hline${ }^{*} 0.281-$ & ${ }^{*} 0.289-$ & & أقل من 5 سنوات \\
\hline \multirow[t]{2}{*}{0.008} & & & $10-5$ \\
\hline & & & أكثر من 10 سنوت \\
\hline
\end{tabular}

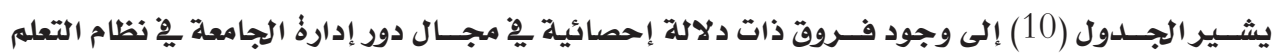

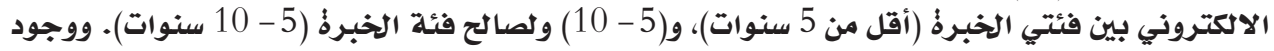

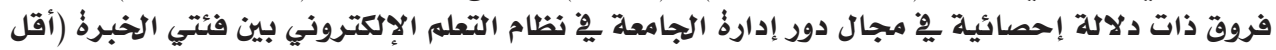

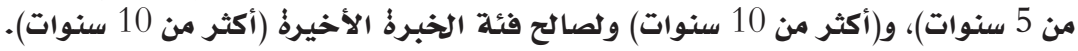

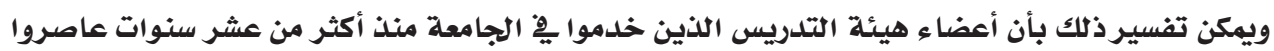

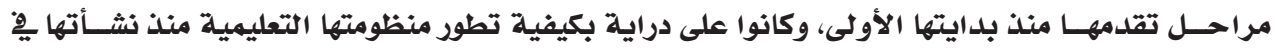

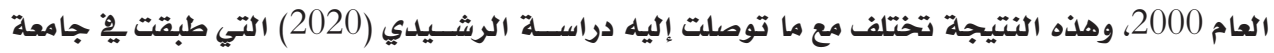

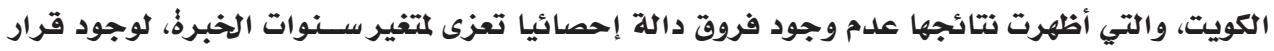

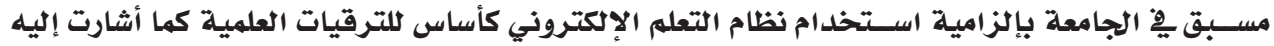

الدراسلة. مساسئ.

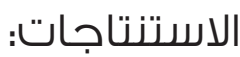

من خلال النتائج، يمكن استنتاج الآتي:

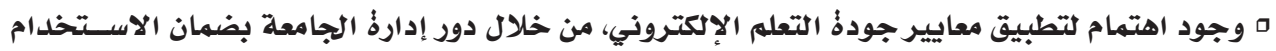

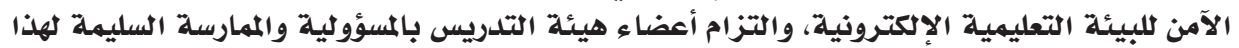
النظام.

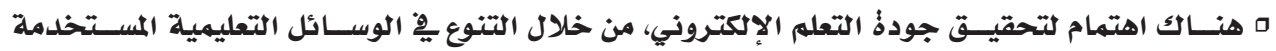

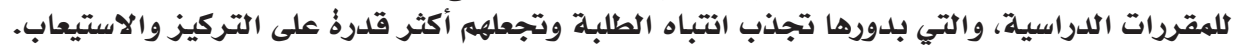

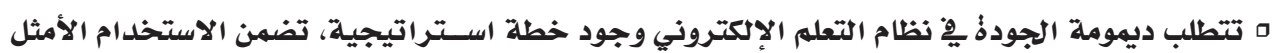

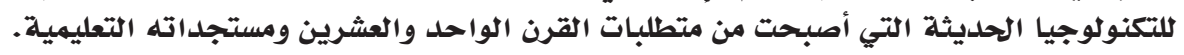

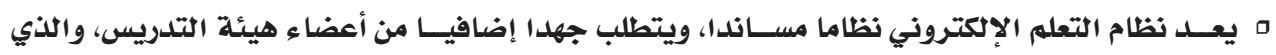
بلدروه يعمل على زيادة الضغوطات النفسية لديهم ويزيل من أعبائهم الوظيفية.

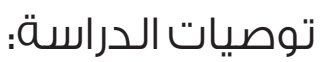

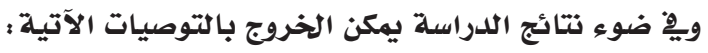

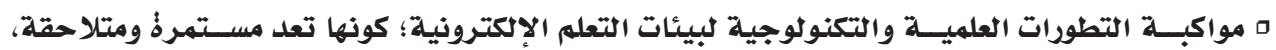

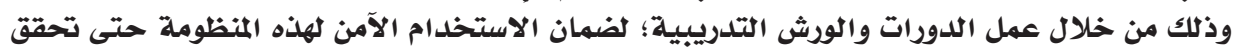

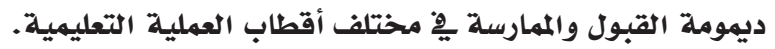




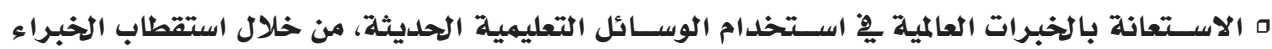

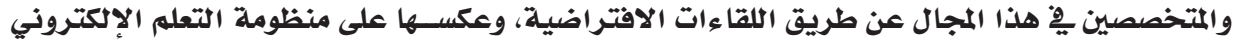
مِِ الجامعة؛ للتكيف مع المستجدات المستقبلية والمحافظة على جودةُ التعله الإلكتروني.

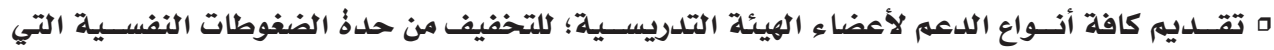

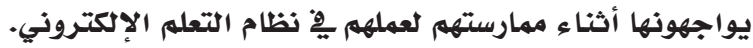

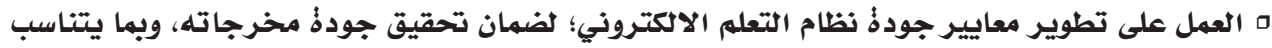

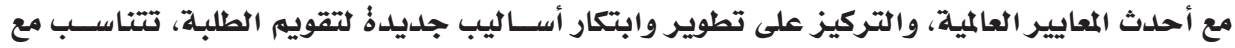

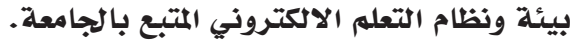

أبو سـريويل، ياسين، إمبارك، إبراهيه، والكايخ، فيصل (2020). إمكانية دمج التعليم الاكتتروني وأثره بِّ.

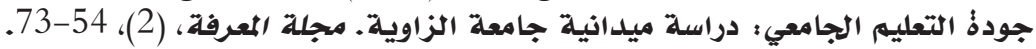

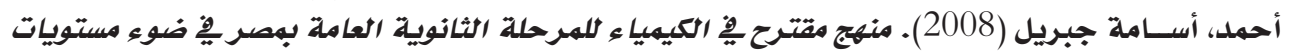

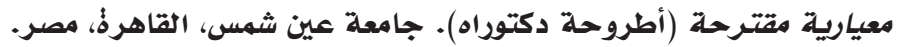

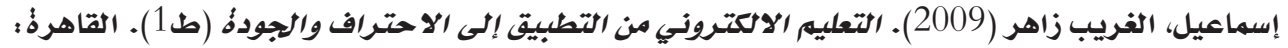
عالم الكتب للنشر والتوزيبع.

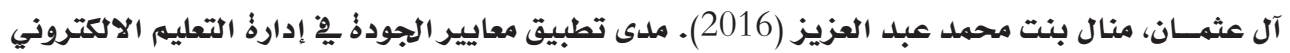

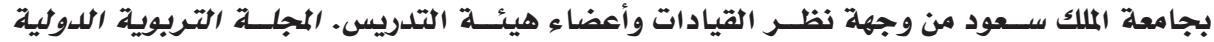
المتخصصة، 5(9)، 167-189.

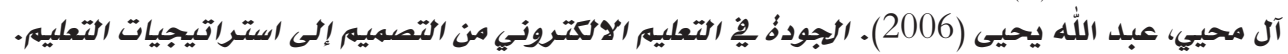

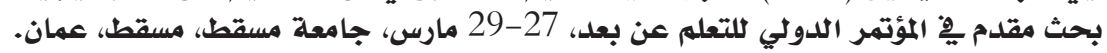

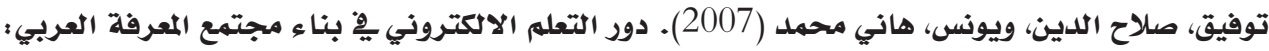

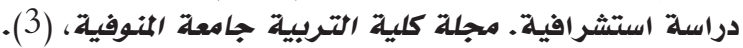

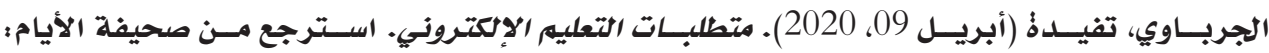
https://bit.ly/3GLFblx

الجمل، سمير سليمان (2020). التعليم الإلكتروني يِّ الجامعات الفلسطينية وتأثيره على مخرجات التهات التعليم

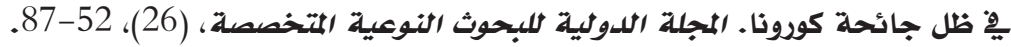

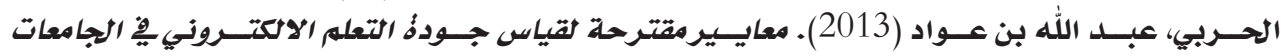

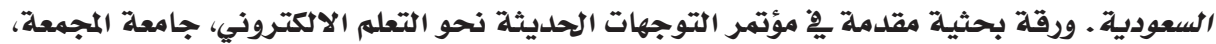
الرياض، السعودية.

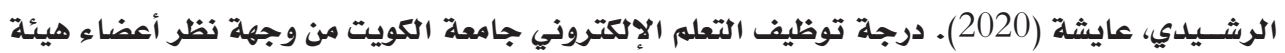

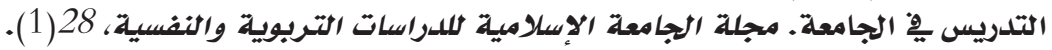

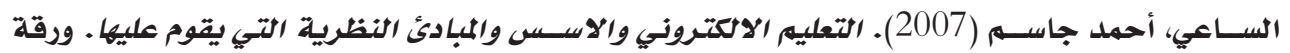

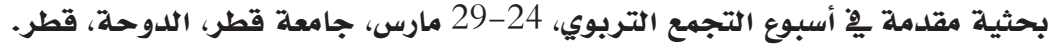

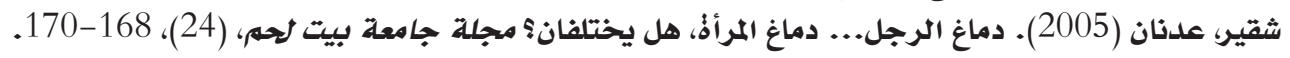

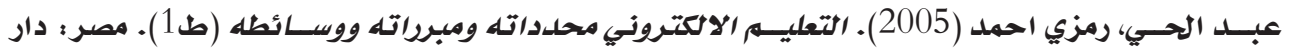

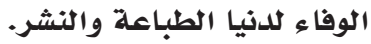

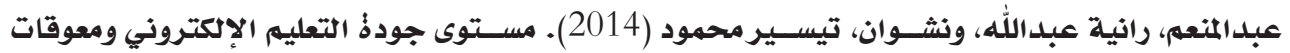

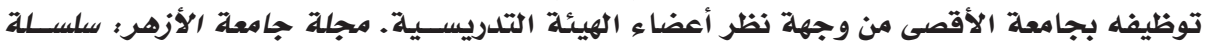

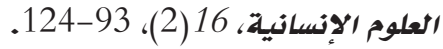




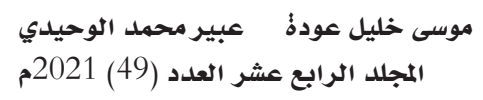

العتيـبي، عبــد المجيد بن ســلمي الروقي (2019). معايير الجــودةٌ يِ أنظمة التعليــهم الالكتروني. المجلة

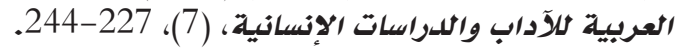

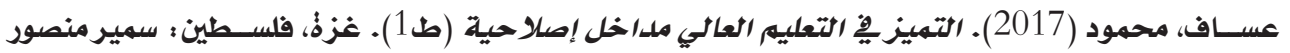

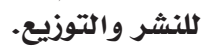

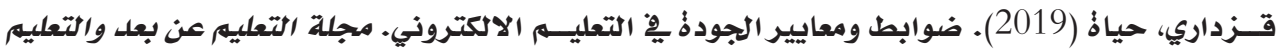
المفتوح، $7($ (13)، 119-148.

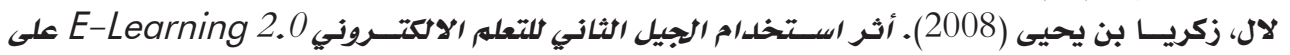

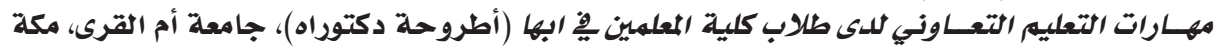

$$
\begin{aligned}
& \text { المكرمة، السعودية. } \\
& \text { المدريـس، عبد الرحمن (2004). إدارةٌ الجودةٌ ِِ التعليم. الرياض : المركز العربي للتدريب التربوي لدول } \\
& \text { الخليج. } \\
& \text { منظار للدراسـات والشؤون والتقارير السياسية (سبتمبر 4، 2021). المنظومة التعليهية بالكويت وتحلديات }
\end{aligned}
$$

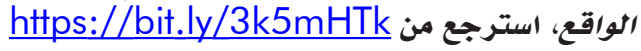

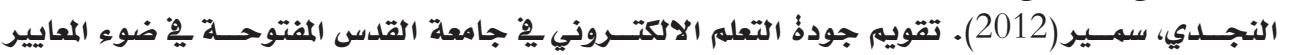

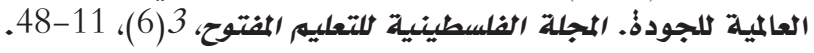

Barker, K. (2002). Canadian recommended e-learning guidelines. Vancouver, BC: Vancouver, BC: FuturEd for Canadian Association for Community Education and Office of Learning Technologies.

Ehlers, U. D. (2004). Quality in e-learning from a learner's perspective. European Journal of Open, Distance and E-learning, 7(1).

Frydenberg, J. (2002). Quality standards in e-learning: A matrix of analysis. International Review of Research in Open and Distributed Learning, 3(2), $1-15$.

Shraim, K. (2020). Quality Standards in Online Education: The ISO/IEC 40180 Framework. International Journal of Emerging Technologies in Learning (iJET), 15(19), 22-36.

Yeung, D. (2003). Toward an effective quality assurance of Web-based learning: The perspective of distance learning students. Turkish Online Journal of Distance Education, 4(1), 1-12.

\section{Arabic References in Roman Scripts:}

Abdelmoneim, Rania Abdullah, wa Nashwan, Tayseer Mahmoud (2014). Mustawaa jawdat altaelim al'iiliktrunii wamueawiqat tawzifih bi Jamieat Al'aqsaa min wijhat nazar 'aeda' alhayyat altadrisiati. Majalat Jamieat Al'azhar: Silsilat Aleulum Al'iinsaniati, 16(2), 93-124.

Abdulhai, Ramzy Ahmed (2005). Altaelim alalkitruniu muhadadatuh wamubariratuh wawasayituh (Tab'a 1). Misr: Dar Alwafa' Lidunya Altibaeat Walnashr. 
Abu Seriwil, Yasin, Embarak, Ibrahim, wa Al-Kaikh, Faisal (2020). Imkaniat dami altaelim alalkitrunii wa'atharuh fi jawdat altaelim aljamieii: Dirasat maydaniat Jamieat Alzaawiatan. Majalat Almaerifati, (2), 54-73.

Ahmed, Osama Jibril (2008). Manhai muqtarah fi alkimia' lilmarhalat althaanawiat aleamat bimisr fi daw' mustawayat mieyariat muqtariha (Utaruhat dukturah). Jamieat Eayn Shams, Alqahirat, Misr.

Al Mohie, Abdullah Yahya (2006). Aljawdat fi altaelim alalkitrunii min altasmim 'iilaa astiratijiaat altaelimi. Bahth muqadam fi Almutamar Alduwalii Liltaealum ean Bued, 27-29 Mars, Jamieat Masqat, Masqat, Oman.

Al Othman, Manal bint Muhammad Abdulaziz (2016). Madaa tatbiq maeayir aljawdat fi 'iidarat altaelim alalkitrunii bijamieat almalik sueud min wijhat nazar alqiadat wa'aeda' hayyat altadrisi. Almajalat Altarbawiat Alduwaliat Almutakhasisati, 5(9), 167-189.

Al-Harbi, Abdullah bin Awad (2013). Maeayir muqtarihat liqias jawdat altaealum alalkutrunii fi aljamieat Alsaeudiati. Waraqat bahthiat muqadimat fi Mutamar Altawajuhat Alhadithat Nahw Altaealum Alalkitrunii, Jamieat Almajamaeati, Alriyad, Alsaeudiati.

Al-Jamal, Samir Suleiman (2020). Altaelim al'iiliktruniu fi aljamieat alfilastiniat watathiruh ealaa mukhrajat altaelim fi zili jayihat kuruna. Almajalat Alduwaliat Lilbuhuth Alnaweiat Almutakhasisati, (26), 52-87.

Al-Jarbawi, Tafaida (Abril 09, 2020). Mutatalibat altaelim al'iilikturunii. Astarjie min Sahifat Al'ayami: https://bit.ly/3GLFblx

Al-Madris, Abdulrahman (2004). Idarat aljawdat fi altaelimi. Alrayad: Almarkaz Alearabia Liltadrib Altarbawii Lidual Alkhalii.

Al-Najdi, Samir (2012). Taqwim jawdat altaealum alalkutrunii fi Jamieat Alquds Almaftuhat fi daw' almaeayir alealamiat liljawdati. Almajalat Alfilastiniat Liltaelim Almaftuhi, 3(6), 11-48.

Al-Otaibi, Abdul Majeed bin Salma Al-Roqi (2019). Maeayir aljawdat fi 'anzimat altaelim alalkitrunii. Almajalat Alearabiat Liladab Waldirasat Al'iinsaniati, (7), 227-244.

Al-Rashidi, Aisha (2020). Darajat tawzif altaealum al'iiliktrunii jamieat alkuayt min wijhat nazar 'aeda' hayyat altadris fi aljamieati. Majalat Aljamieat Al'iislamiat Lildirasat Altarbawiat Walnafsiati, 28(1).

Al-Saei, Ahmed Jasim (2007). Altaelim alalkitruniu walasis walmabadi alnazariat alati yaqum ealayha. Waraqat bahthiat muqadimat fi Usbue Altajamue Altarbawi, 24-29 Mars, Jamieat Qatar, Aldawha, Qatar.

Assaf, Mahmoud (2017). Altamayuz fi altaelim aleali madakhil 'iislahia (Taba'a 1). Ghazat, Filastin: Samir Mansour Lilnashr Waltawziei. 


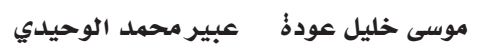

Ismail, Al-Gharib Zaher (2009). Altaelim alalkitruniu min altatbiq 'iilaa alahtiraf waljawda (Taba'a 1). Alqahiratu: Ealam Alkutub Lilnashr Waltawziei.

Kazdari, Hayat (2019). Dawabit wamaeayir aljawdat fi altaelim alalkitruni. Majalat Altaelim ean Bued Waltaelim Almaftuhi, 7(13), 119-148.

Lal, Zakaria bin Yahya (2008). Athar astikhdam aljil althaani liltaealum alalktrunii E-Learning 2.0 ealaa maharat altaelim altaeawunii ladaa tulaab kuliyat almuealimin fi Abiha (Utaruhat dukturah), Jamieat Umm Alquraa, Makat Almukaramati, Alsaeudiatu.

Minzar Lildirasat Walshuwuwn Waltaqarir Alsiyasia (Sibtambar 4, 2021). Almanzumat altaelimiat bi Alkuayt watahadiyat alwaqie, Aistarjae min https://bit.ly/3k5mHTk

Shuqayr, Adnan (2005). Dimagh alrajulu... dimagh almar'ati, hal yakhtalifani? Majalat Jamieat Bayt Laham, (24), 168-170.

Tawfiq, Salah El-Din, and Younis, Hani Mohamed (2007). Dawr altaealum alalkitrunii fi bina' mujtamae almaerifat alearabii: Dirasatan aistishrafiati. Majalat Kuliyat Altarbiat Jamieat Almanufiati, (3). 